\title{
Mobbing ve Örgütsel Sessizliğin İş Performansına Etkisi: Çanakkale İlinde Bir Araştırma ${ }^{1}$
}

\author{
DOI: 10.26466/opus.635147 \\ * \\ Polat Yücekaya * - Özkan İmamoğlu** \\ * Dr.Öğr.Üyesi, ÇOMÜ, Gelibolu Piri Resi MYO/Gelibolu/Çanakkale/ Türkiye \\ E-Posta: polatyucekaya@gmail.com ORCID: 0000-0002-5000-9711 \\ **Öğr.Görevlisi, Amasya Üniversitesi, Taşova/Amasya/Türkiye \\ E-Posta: ozkan.imamoglu@amasya.edu.tr ORCID: 0000-0002-1646-9781 \\ Öz
}

Bu araştırmanın amacl; mobbing ve örgütsel sessizlik algısının çalışanların iş performansına etkilerini belirlemektir. Bu araştırmada Çanakkale ilinde görevli 341 kamu çalş̧anı ile yüz yüze anket uygulaması yapılmak suretiyle 2019 yılı Ocak Şubat aylarını kapsayan dönemde, kolayda örneklem yöntemi ile veri toplanmıştır. Ankette örgütsel sessizlik için Dyne vd. (2003) tarafindan geliştirilen ve 30 ifadeden oluşan ölçek kullanılmıştır. Mobbing için ise, Leymann (1993) geliştirilen ve 36 ifadeden oluşan ölçekten yararlanılmıştır. İş performansı ölçeği için Staples vd. (1999) tarafından geliştirilen ve 4 ifadeden oluşan ölçek kullanılmıştır. Toplanan verilere T testi, ANOVA, güvenilirlik analizi, faktör analizi, korelasyon ve regresyon, analizleri yapılmıştır. Araştırmada yapılan regresyon analizi sonuçlarına göre, mobing algısı ile iş performansı arsında negatif bir ilişki olduğu ve ters yönde etkilediği tespit edilmiştir. Örgütsel sessizlik algısı da çalışanların iş performansını negatif yönde etkilemekte olup ters yönde etkilemektedir. Bu araştırma sonuçlarnna göre yöneticiler için ve bundan sonraki çalışmaları yürütecek araştırmacılar için çeşitli öneriler sunulmştur.

Anahtar Kelimeler: Mobbing, Örgütsel Sessizlik, İş Performansı

\footnotetext{
${ }^{1}$ Bu çalışma II. BOR kongresinde özet bildiri olarak sunulmuştur.
} 


\title{
The Effect of Mobbing and Organizational Silence on Job Performance: A Research on Çanakkale Province
}

\begin{abstract}
The aim of this research is to determine the relationship between mobbing on organizational silence and job performance. In this research, a survey was conducted to 341 public employee who work in Çanakkale province and data was collected by convenience sampling method in the period covering January to February 2019. For organizational silence, a scale consisting of 30 expressions developed by Dyne vd. (2003) was used. The scale taken from the studies of Leymann (1993) and consisting of 36 expressions was used in the survey for mobbing. For job performance, a scale consisting of 4 expressions developed by Staples vd. (1999) was used. T test, ANOVA, reliability analysis, factor analysis, correlation and regression analyzes were used for the data. According to the results of regression tests carried out in the research, there is a negative relationship between the mobbing perceptions and job performance of employees. It is also indicated that there is a negative relationship between the nepotism perceptions and organizational citizenship behaviors of employees. It is also indicated that there is a positive relationship between the organizational silence perceptions and job performance of employees and they are affected in the reverse direction.According to the results of this research, various suggestions are developed fort he managers and researchers who will carry out the following studies
\end{abstract}

Keywords: Mobbing, Organizational silence, Job Performance 


\section{Giriş}

Insanlar toplum halinde yaşamaktadırlar. Bu nedenle insanlar arası ilişkilerde şiddet kaçınılmaz olan bir olgudur. Çalışma yaşamında da fiziksel ya da psikolojik olarak çalışanların birbirine şiddet uygulamalarına sıklıkla rastlanılmaktadır. Şiddetin iş hayatındaki olumsuz etkilerinin azaltılamasına yönelik birtakım cezai yaptırımlar getirilmek istenmesi sonucu çalışma yaşamında şiddet daha da önemli hale gelmiş ve tartışılmaya başlanmıştır.

Şiddet kavramı TDK sözlüğünde "Karşıt görüşte olanlara kaba kuvvet kullanma" olarak tanımlanmaktadır. Bir başka tanımda ise benzer şekilde "sertlik, sert ve katı davranış, kaba kuvvet kullanma" olarak ifade edilmektedir (Ünsal 1996). Hukuksal açıdan bakılacak olursa TCK 86 ve 87 . Maddeleri şiddet eyleminin gerçekleştirilmesine engel olma ve şiddet suçunu cezalandırmaya yönelik olarak düzenlenmiştir. TCK “Kasten başkasının vücuduna acı veren veya sağlığının ya da algılama yeteneğinin bozulmasını şiddet eylemi" olarak tanımlamaktadır. Fiziksel şiddet uygulama eyleminin gerçekleşmesini önleme amacıyla ceza-i müeyyide olarak ağır bir yaptırım olarak belirlemiştir. Sanayi devriminde çalışanların daha çok fiziksel olarak iş yapmaları nedeniyle iş yaşamında daha çok fiziksel şiddeti önlemeye yönelik çalışmalar yapılırken; bilgi toplumunda çalışanlar fikri emek ile iş yapmaya başlamışlardır. Bu nedenle iş yaşamında daha çok psikolojik şiddet uygulamalarına rastlanmaktadır. İş yaşamında fiziksel şiddet yerine psikolojik şiddet uygulamanın sonuçları daha ağır olabilmektedir (Laleoğlu ve Özmete, 2013). Bir kavram olarak mobbingi 1960'lı yıllarda Konrad Lorenz adlı bilim insanı ilk kez kullanmıştır. Lorenz, Hayvanların davranışlarını incelemesi esnasında, nispeten küçük gruplar halinde olan hayvanların kendilerinden daha güçlü olan bir başka hayvana toplu olarak saldırması ve uzaklaştırması durumunu açıklamak için mobbing kavramını kullanmıştır (Westhues, 2003). Mobbing bir işyerinde bir ya da daha çok çalışanın, başka bir çalışanı yıpratma, engelleme, acı ve keder duymasını sağlamak amacıyla sürekli olarak tekrarlanan olumsuz davranışlar sergilemesi durumudur (Brodsky, 1976). Leymann (1990) ise mobbingi tek bir bireye uygulanan "düşmanca ve ahlaki olmayan" davranışlar olarak tanımlamaktadır. Kavram tanımlanırken belirli bir zaman süresince tekrarlanması gerekmektedir. Bir kez gerçekleşen olay ve durumlar mobbing olarak kabul edilmemektedir (Hoel et all, 2001). Bu davranışların sıklıkla tekrarlanmasından en az 
haftada bir defa ve en az altı ay gibi uzun bir zaman boyunca devam etmesi gerekmektedir (Laleoğlu ve Özmete, 2013). Mobbing çalışana uygulanan duygusal saldırılardır. Yani, çalışanın itibarını ve iş yerindeki statüsünü zedelemek maksadıyla "kötü davranışlarda bulunma, taciz, incitme, dışlama veya işine zarar verme" davranışlardır (Zapf, 1999). Mobbing olumsuz ve sürekli tekrarlanan davranışlardır (Thylefors, 1987). Bu duruma ilave olarak mobbingin tarafları arasında güç açısından farklılık bulunması söz konusudur (Salin, 2003). Mobbing beş aşamada gerçekleşmektedir. Anlaşmazlığın başlaması mobbingin ilk aşamasıdır. İkinci aşamada ise saldırgan eylemler artmaktadır. Üçüncü aşamada, işletme yönetiminde bulunanlar da negatif davranışlar içinde yer almaya başlarlar. Dördüncü aşamada ise mobbinge maruz kalan kişiler ruhsal bozukluğu olan kişiler ve sorunlu çalışanlar olarak tanımlanmaktadır. Son aşamada mobbinge maruz kalan kişiler aşırı stres altındadır ve psikolojik bozukluklar başlamıştır. Bu aşama aynı zamanda çalışanın işine son verilme aşamasıdır (Davenport et all, 2003). Literatürde mobbing ile ilgili çalışmalar incelendiğinde, mobbingin en önemli etkisinin çalışan performansı üzerindeki olumsuz etkisi olduğu görülmektedir (Davenport et all, 2003; Çalış Duman ve Akdemir, 2016). Sadece bireysel performans üzerinde değil örgüt performansı üzerinde de olumsuz etkileri söz konusudur (Divincová ve Siváková, 2014; Korkmaz vd., 2014; Çınar ve Akpunar, 2017). Mobbing iş tatminini azaltırken çalışanın kendine güvenini yok eder, bunun yanında işten ayrılma niyetini artırarak çalışanların kariyer planlarının değişmesine neden olabilmektedir (Zapf, 1999).

Örgütsel sessizlik ise TDK sözlüğünde "Ortalıkta gürültü olmama durumu, sükût" olarak tanımlanmaktadır. Davranışsal bir olgu olark ise ses ile sessizlik kavramları birbirine zıt kavramlardır. Fakat iki kavram da birçok faktörü içinde barındırmaktadır (Dyne et all. 2003). Hirschman (1970) ilk defa örgütsel ses kavramını ele almış ve iş tatminsizliği durumuna karşı verilen tepki olarak ifade etmiştir. Örgütsel sessizlik ise bir kavram olarak ilk kez Morison ve Miliken (2000) tarafından kullanmıştır. Çalışmalarında örgütsel sessizliği, çalışanların "aktif ve bilinçli eylemi“" olarak tanımlamışlar ve işletmede çalışanların bilgi, fikir ve düşüncelerinin bilerek saklanması olarak tanımlamışlardır. Benzer şekilde Pinder ve Harlos (2001) da sessizlik davranışını, çalışanların işletmeye ilişkin konularda bilgi ve fikirlerini yöneticilerle paylaşmak yerine söylemekten kaçınmaları olarak ifade etmişler- 
dir.Bundan önceki araştırmalar incelendiğinde sessizlik davranışına neden olan etmenler "korkular ve inançlar" (Miliken vd., 2003; Gardezi vd., 2009) "örgütsel norm ve kuarllar" (Premaux and Bedeian, 2003; Yalçın ve Baykal, 2012) ; "organizasyondaki algilanan destek kavramı" (Dyne et all., 2003) ; Örgütsel güven eksikliği (Nikolaou et all. 2011) olarak ifade edildiği görülmektedir. Çalışanların sessizlik davranışı sergilemeleri işletmeler açısından zararlı sonuçlar doğurmaktadır. Sorunların ifade edilmemesi, korkunun işletmede hakim olması, katı kurallar ve normların mevcut oluşu gibi nedenlerle çalışanlar sessizlik davranışı sergilemekte ve bu durum iş tatminini ve iş performansını olumsuz etkilemektedir (Morrison ve Milliken 2000; Çakıcı, 2010). Bunun yanında işten ayrılma niyetini artırdığı, yenilikçi fikirlerin ortaya çıkmasını engellediği, bağlılık duygusunu azalttığı ve sessizlik davranışı gösteren çalışan üzerinde birçok kişisel probleme sebep olduğu ifade edilmektedir (Vakola ve Bouradas, 2005; Donaghey et all, 2011). Işletmeler açısından çalışanların bireysel performansı son derece önemlidir. Işletmelerin en değerli kaynağı insan kaynağıdır. Bir işletme ancak çalışanların performansı doğrultusunda başarıya ulaşabilir (Benligiray, 2004). Rekabetin arttığı, yenilik ve değişimlerin çok hızlı gerçekleştiği, dünyada küreselleşmenin yaşandığı ve bilgiye ulaşmanın kolaylaştığı bir dönemde işletmeler kaynaklarını en etkin şekilde değerlendirmek durumundadır. Insan kaynağının performansının artırılması sürdürülebilir kara ulaşmada en etkili araçtır. Performans değerleme kriterlerinin objektif olması, yüksek performanslı çalışan ile düşük performansın ayrı değerlendirilmesi, tutumluluk, etkililik ve verimlilik ilkesini yönetim aracı olarak benimsenmesi gerekmektedir (Çevik vd., 2008). Çalışanların fiziksel ve psikolojik olarak hazır olmalarının işletmenin amaçlarına ulaşmasındaki en önemli unsurlar olduğunun dikkate alınması gerekmektedir (Yazıcıoğlu, 2010). Çalışanların performansları motivasyonlarına bağlıdır. Motivasyonun artırılması ise maddi (ücret, prim vb.) ve maddi olmayan (takdir, taltif vb) ödüllerin verilmesine bağlıdır (Tunçer, 2013).

\section{Yöntem}

Bu araştırmanın amacı, mobbing ve örgütsel sessizlik algısının çalışanlarıniş persormansına etkilerini belirlemektir. Bu amaçla mobbing ve örgütsel sessizlik ile iş persormansı arasında nasıl bir ilişki vardır? Mobbing, örgütsel 
sessizlik algısı ve çalışanların iş performanslanı demografik özelliklerine göre farklılaşmakta mıdır? Mobbing, iş persormansını etkir mi? Örgütsel sessizlik algısı iş persormansını etkiler mi? Sorularına bu araştırmada cevap aranmaktadır.Bu araştırmada kolayda örneklem yöntemi kullanılmıştır. Araştırmanın varsayımları ise şunlardır: Örneklemin ana kütleyi temsil yeteneğinin yüksek olduğu varsayılmaktadır. Ankette yer alan ölçeklerin araştırma amacına uygun olduğu varsayılmaktadır. Anket katılımcılarının ifadeleri içtenlikle ve doğru olarak cevapladıkları varsayılmaktadır. Verileri analiz için kullanılan istatistiki analiz yönteminin uygun olduğu varsayılmaktadır.

Bu araştırma mobbing, örgütsel sessizlik ve iş persormansı değişkenlerini ölçmek üzere tasarlanmış ölçeklerle sınırlıdır. Araştırmaya katılanlar ise, Çanakkale'de görev yapmakta olan kamu personeli ile sınırlandırılmıştır. $\mathrm{Bu}$ araştırmada ele alınan mobbing, örgütsel sessizlik ve iş persormansı kavramları zaman içerisinde değişebilecek kavramlardır. Bu nedenle araştırmanın bulguları uygulandıkları zaman periyoduyla sınırlıdır. Araştırmanın bir diğer kısıtı ise maliyet kısıtıdır.

\section{Araştırmanın Yöntemi Ve Modeli}

Çalışmada anket uygulanarak veri toplanmıştır. Bu amaçla Çanakkale'de görev yapmakta olan 341 kamu çalışanı ile yüz yüze anket uygulaması yapılmak suretiyle 2019 yılı Ocak Şubat aylarını kapsayan dönemde, kolayda örneklem yöntemi ile veri toplanmıştır. Ankette örgütsel sessizlik için Dyne vd. (2003) tarafından geliştirilen ve 30 ifadeden oluşan ölçek kullanılmıştır. Mobbing için ise, Leymann (1993) geliştirilen ve 36 ifadeden oluşan ölçekten yararlanılmıştır. İş performansı ölçeği için Staples vd. (1999) tarafından geliştirilen ve 4 ifadeden oluşan ölçek kullanılmıştır. Ankette katılımcıları demografik özellikleri için ise beş soru bulunmaktadır. Anketteki ifadeler Likert ölçeğinde hazırlanmış olup, cevaplar ise "Kesinlikle katılmıyorum, katılmıyorum, kararsızım, katılıyorum, kesinlikle katılıyorum" olmak üzere beş dereceli bir skalada değerlendirilmiştir. Toplanan verilere $t$ testi, ANOVA, güvenilirlik analizi, faktör analizi, korelasyon ve regresyon, analizleri yapılmıştır. Araştırma modelinde demografik özellikler, mobbing, örgütsel sessizlik ve iş performansından oluşan değişken grubu bulunmaktadır. 


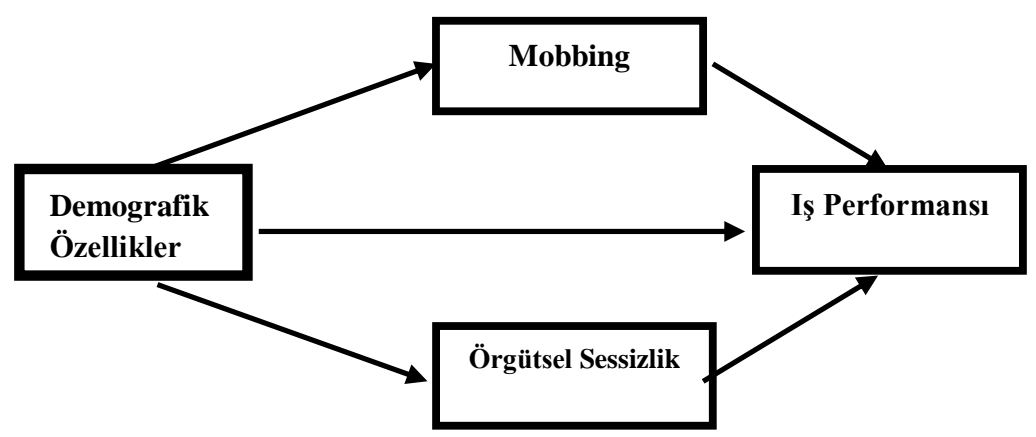

Bu çalışmada katılımcıların demografik özelliklerinin, mobbing algılarının ve örgütsel sessizlik algılarının iş performanslarına etkisini tespit etmek için şekil 1'de görülen model oluşturulmuştur. Araştırma sorularına ve literatüre istinaden oluşturulan hipotezler şu şekildedir:

- H1: Katılımcıların mobbing algıları demografik özelliklerine göre farkl1laşmaktadır.

- H1a: Katılımcıların mobbing algıları cinsiyetlerine göre farklılaşmaktadır.

○ H1b: Katılımcıların mobbing algıları medeni durumlarına göre farklılaşmaktadır

- H1c: Katılımcıların mobbing algıları yaşlarına göre farklılaşmaktadir.

○ H1d: Katılımclların mobbing eğitim seviyelerine göre farklılaşmaktadir.

- H1e: Katılımcıların mobbing çalışma yılına göre farklılaşmaktadır.

- H2: Katılımcıların örgütsel sessizlik algıları demografik özelliklerine göre farklılaşmaktadır.

○ H2a: Katılımcların örgütsel sessizlik algıları cinsiyetlerine göre farklilaşmaktadır.

○ H2b: Katılımcların örgütsel sessizlik algıları medeni durumlarına göre farklılaşmaktadır.

○ H2c: Katılımcıların örgütsel sessizlik algıları yaşlarına göre farklılaşmaktadır.

○ H2d: Katılımcıların örgütsel sessizlik algıları eğitim seviyelerine göre farklılaşmaktadır. 
○ H2e: Katılımcların örgütsel sessizlik algıları çalışma yılına göre farklılaşmaktadır.

- H3: Katılımcıların iş performansları demografik özelliklerine göre farklılaşmaktadır.

- H3a: Katılımcıların iş performansları cinsiyetlerine göre farklılaşmaktadır.

- H3b: Katılımcıların iş performansları medeni durumlarına göre farklılaşmaktadır.

- H3c: Katılımcıların iş performansları yaşlarına göre farklılaşmaktadir.

- H3d: Katılımcların iş performansları eğitim seviyelerine göre farklılaşmaktadır.

- H3e: Katılımcıların iş performansları çalışma yılına göre farklılaşmaktadır.

- H4: Katılımcıların mobbing algıları iş performanslarını etkiler

- H5: Katılımcıların örgütsel sessizlik algıları iş performanslarını etkiler

\section{Örneklem}

Tablo 1. Katılımcılarn Demografik Özellikleri

\begin{tabular}{lll}
\hline & $\mathbf{N}$ & $\%$ \\
\hline Cinsiyet & & \\
\hline Erkek & 191 & 56 \\
Kadın & 150 & 44 \\
Toplam & 341 & 100,0 \\
\hline Medeni durum & & \\
\hline Evli & 211 & 61,9 \\
Bekar & 130 & 38,1 \\
Toplam & 341 & 100,0 \\
\hline Yaş & & \\
\hline $18-25$ & 83 & 24,3 \\
$26-33$ & 88 & 25,8 \\
$34-41$ & 90 & 26,4 \\
$42-49$ & 47 & 13,8 \\
$50+$ & 33 & 9,7 \\
Toplam & 341 & 100,0 \\
\hline Eğitim Seviyesi & & \\
\hline Ilköğretim & 25 & 7,3 \\
Lise & 97 & 28,4 \\
Önlisans & 75 & 22 \\
Lisans & 128 & 37,5 \\
Lisansüstï & 16 & 4,7 \\
Toplam & 341 & 100,0 \\
\hline
\end{tabular}




\begin{tabular}{lll}
\hline Çalışama Süresi & & \\
\hline 1-5 Y1l & 81 & 23,8 \\
6-11 Y1l & 93 & 27,3 \\
12-17 Y1l & 58 & 17 \\
18-23 Yll & 61 & 17,9 \\
24 Y1l ve fazla & 48 & 14,1 \\
\hline Toplam & 341 & $\mathbf{1 0 0 , 0}$ \\
\hline
\end{tabular}

Katılımcıların demografik sorulara verdiği yanıtlara göre \%56,'sı kadın, \%4'ü erkek çalışanlardan oluşmakta olup bunların \%61,9'u evli; \%38,1'i ise bekârdır. Katılımcıların \%24,3'ü 18-25 yaş aralığında; \%25,8'i 26-33 yaş aralığında; \%26,4'ü 34-41 yaşları arasında; \%13,8'i 42-49 yaşları ve \%9,7'si 50 yaş ve üzerindedir. Katılımcıların eğitim durumları ise \%7,3’ü ilköğretim; $\% 28,4$ 'ü lise; \%22'si önlisans; \%37,5'i lisans ve \%4,7'si lisansüstü eğitim seviyesindedir. Katılımcların çalışma süreleri incelendiğinde \%23,8'i 1-5 yıl; $\% 27,3$ 'ü 6-11; \%17'si 12-17 y1l; \%17,9'u 18-23 yıl; \%14,1'inin ise 24 yll ve fazlası bir çalışma hayatının olduğu görülmektedir.

\section{Veri toplama araçlan}

Bu bölümde ölçeklere ilişkin geçerlilik, güvenilirlik ve faktor analizlerine ilişkin bilgiler verilmektedir.

Güvenilirlik ve Geçerlilik Analizi : Verilerin güvenilirliğini test etmek ve doğrulamak analizlerin doğruluğu ve genellenebilirliği açısından büyük önem arz etmektedir. Bu çalışmada Cronbach alfa katsayısı hesaplamaya dayanan güvenilirlik analizi yapılmıştır. Croanbach alfa katsayısı 30 ifadeden oluşan örgütsel sessizlik ölçeği için 0,$943 ; 4$ ifadeden oluşan iş performansı ölçeği için ,889 ve 36 ifadeden oluşan mobbing ölçeği için ,949 olarak tespit edilmiştir. Bu sonuç ölçekleri güvenilirliklerinin yüksek olduğunu göstermektedir.

Tablo 2. Güvenilirlik Analizi

\begin{tabular}{lll}
\hline Ölçek Adı & Cronbach alfakatsayısı & İfade Sayısı \\
\hline Örgütsel Sessizlik &, 938 & 30 \\
İş performansı &, 889 & 4 \\
Mobbing &, 949 & 36 \\
\hline
\end{tabular}


Faktör analizinin uygulanabilmesi için öncelikle Kaiser Meyer Olkin $(\mathrm{KMO})$ ve Bartlett testi yapılmıştır. KMO testi veri setinin alındığı örneklem yeterliliğini, Bartlett testi ise korelasyon matrisinin birim matristen farklı olduğunu test etmektedir.

Tablo 3. KMO and Bartlett's Testi

\begin{tabular}{lllll}
\hline & & Örgütsel Sessizlik & İş performansı & Mobbing \\
\hline \multirow{2}{*}{ K-M-O Örneklem Yeterliliği Ölçümü } &, 890 &, 686 &, 906 \\
\hline \multirow{3}{*}{ Bartlett's Küresellik Testi } & Ki kare yaklaşımı & 4644,371 & 1071,57 & 8162,256 \\
\cline { 2 - 5 } & Serbestlik Derecesi 435 & 6 & 630 \\
\cline { 2 - 5 } & Anlamlılık Düzeyi ,0001 & 0,0001 & 0,0001 \\
\hline
\end{tabular}

Tablo 3'te verilen ölçeklere ait KMO değerlerinden Örgütsel Sessizlik ölçeği ,890 olarak bulunmuş ve çok iyi seviyededir. İş performansı ölçeği KMO değeri ,686 olup iyi seviyededir. Mobbing ölçeğinin KMO değeri ise ,906 değeri ile çok iyi seviye olarak değerlendirilmektedir. Veri setinin KMO değeri 0,50'nin üzerinde olduğundan ve Bartlett testi de $\mathrm{p}=0,00$ önem derecesinde anlamlıdır. Barttlet testinin anlamlı olması korelasyon matrisinin birim matristen farklı olduğu sonucunu göstermektedir (Altunışık vd., 2012). Bu nedenle veri seti faktör analizine uygun bulunmuştur.

\section{Faktör analizleri:}

Örgütsel Sessizlik Ölçeğinde 16 ve 17. soruların birden fazla faktörle ilişkili olması sebebiyle analizden çıkarılmıştır. Bu sorular çıkarıldıktan sonra güvenilirlik analizi tekrarlanmış Cronbach's Alpha 0,938 olarak tespit edilmiştir.

Faktör analizi sonuçuna göre örgütsel sessizlik beş faktör olarak ayrılmıştır. Toplam açıklanan varyans $\% 76,169$ olup beş faktöre ayrılan örgütsel Sessizlik ölçeğinde kendini koruma amaçlı sessizlik varyansın \%39,3'ünü açıklamaktadır. İş ortamını iyileştirme amaçlı sessizlik varyansın \%19,2'sini; ve kabullenici sessizlik ise varyansın $\% 7,06$ 'sını açıklamaktadır. İlişkisel sessizlik varyansın \%5,4'ünü; İş yerini koruma amaçlı sessizlik ise varyansın $\% 4,7^{\prime}$ sini açıklamaktadır. 
Tablo 4. Örgütsel Sessizlik Ölçeği Faktör Analizi

\begin{tabular}{|c|c|c|}
\hline Faktörler ve Değiskenler & $\begin{array}{l}\text { Faktör } \\
\text { Yükü }\end{array}$ & $\begin{array}{l}\text { Varyansın } \\
\text { Açıklanm } \\
\text { Oranı }\end{array}$ \\
\hline Faktör 1 Kendini Koruma Amaçlı Sessizlik & & $\% 39,388$ \\
\hline İşyerinde kendimi korumak için işyerindeki bazı olayları görmezlikten gelirim. & ,836 & \\
\hline İşyerinde kendimi korumak için iyileştirmeye yönelik öneriler vermem &, 829 & \\
\hline Sonuçlarından çekindiğim için fikirlerimi söylemem. &, 819 & \\
\hline Sonuçlarından çekindiğim için ilgili bilgileri paylaşmam &, 812 & \\
\hline $\begin{array}{l}\text { Korkutulduğum (cezalandırılma, işten çkarılma, terfi edememe korkusu vb. gibi) için, } \\
\text { sorunların çözümlerine ilişkin fikirlerimisöylemem. }\end{array}$ & ,753 & \\
\hline Kendimi korumak için tartışmayı başkalarının üzerine yönlendiririm. & 697 & \\
\hline Kendimi korumak için çalışma arkadaşlarımla hemfikir olurum & 677 & \\
\hline Faktör 2 İş Ortamını İyileştirme Amaçı Sessizlik & & $\% 19,216$ \\
\hline İşyerimdeki diğer kişiler katılmasa bile, işim hakkındaki fikirlerimi açıklarım. & 914 & \\
\hline İşyerimin yararını gözeterek işbirliği içerisinde sorunlara çözüm önerisi getiririm. &, 889 & \\
\hline İsyerimi etkileyen konularla ilgili öneriler sunarım. &, 882 & \\
\hline İşyerimin yararına olabilecek yeni projeler için fikirlerimi açıkça paylaşırım. &, 859 & \\
\hline İsyerimi düşündüğüm için işyerine ait özel bilgileri korurum. &, 824 & \\
\hline İsyerime faydalı olacak değişimler için fikirler öneririm. & ,789 & \\
\hline İşyerime zarar vereceğini düşündüğüm bir bilgiyi açı̆g çıkarmam & ,736 & \\
\hline Faktör 3 Kabullenici Sessizlik & & $\% 7,063$ \\
\hline Bir değişiklik yaratmayacağını düşündüğüm için fikirlerimi beyan etmek istemem. & ,898 & \\
\hline Sorunlara ilişkin çözüm önerilerimi kendime saklarım. &, 846 & \\
\hline Değişime yönelik konularda öneri sunma konusunda isteksizimdir. & ,781 & \\
\hline $\begin{array}{l}\text { Fark yaratacağın düşünmediğim için iyileştirme-geliştirme çalışmalarına ilişkin fikirlerimi } \\
\text { söylemem. }\end{array}$ & 753 & \\
\hline İş geliştirmeye yönelik fikirlerimi ilk amirime söylememeyi tercih ederim. & ,613 & \\
\hline Faktör 4 İlişkisel Sessizlik & & $\% 5,496$ \\
\hline Verilen kararlara uymakla birlikte ara sıra yeni fikirlerimi de söylerim &, 829 & \\
\hline Çalışma arkadaşlarımın önerilerini desteklemeyi tercih ederim & ,773 & \\
\hline $\begin{array}{l}\text { Öneride bulunma konusunda kendimi yeterli görmediğim için çalışma arkadaşlarımı } \\
\text { fikirlerini desteklerim }\end{array}$ & ,631 & \\
\hline Sorunların çözümlerinde arkadaşlarının fikirlerine uyarım. & ,619 & \\
\hline $\begin{array}{l}\text { Önerimin grup kararlarında bir değişiklik yaratmayacağını düşündüğüm için grup kararla- } \\
\text { rına katılırım. }\end{array}$ & ,612 & \\
\hline Faktör 5 İş yerini Koruma Amaçlı Sessizlik & & $\% 4,706$ \\
\hline İşyerimin yararı için işimle ilgili özel bilgileri korurum. &, 812 & \\
\hline Örgütsel sırları söylemem için yapılan baskılara direnirim. &, 761 & \\
\hline $\begin{array}{l}\text { İşyeri dayanışma ortamını bozmamak için işyeri ile ilgili gizli bilgileri başkalarıyla paylaş- } \\
\text { mam. }\end{array}$ & ,723 & \\
\hline TOPLAM & & $\% 76,169$ \\
\hline
\end{tabular}


Tablo 5. Iş Performans Ölçeği Faktör Analizi

\begin{tabular}{lll}
\hline Faktörler ve Değiskenler & $\begin{array}{l}\text { Faktör } \\
\text { Yükü }\end{array}$ & $\begin{array}{l}\text { Varyansın } \\
\text { Açıklanma } \\
\text { Oranı }\end{array}$ \\
\hline Faktör 1 & \%75,497 \\
\hline İş arkadaşlarım verimli (performansı yüksek) bir personel olduğumu düşünür &, 868 \\
\hline Verdiğim hizmetlerin kalitesinden memnunum &, 856 \\
\hline Verimli (performansı yüksek) bir personel olduğuma inanırım. &, 852 \\
\hline Yöneticilerim verimli (performansı yüksek) bir personel olduğumu düşünür &, 831 \\
\hline TOPLAM & & \multirow{2}{*}{$\% \mathbf{7 5 , 4 9 7}$} \\
\hline
\end{tabular}

Tablo 5'de görüldüğü gibi beyana dayalı performans ölçeği tek faktör altında toplanmakta olup toplam açklanan varyans \%74,551 olarak bulunmuştur.

Tablo 6. Iş Performans Ölçeği Faktör Analizi

\begin{tabular}{|c|c|c|}
\hline Faktörler ve Değiskenler & $\begin{array}{l}\text { Faktör } \\
\text { Yükü }\end{array}$ & $\begin{array}{l}\text { Varyansın } \\
\text { Açıklanma oranı }\end{array}$ \\
\hline Faktör 1 - Fiziksel şiddet & & $\% 37,563$ \\
\hline Fiziksel şiddete maruz kaldınız mı? & 886 & \\
\hline Gözünüzü korkutmak için hafif şiddet uygulandı mı? & 854 & \\
\hline Fiziksel şiddet tehditleri aldınız mı? & 801 & \\
\hline Doğrudan cinsel tacize uğradınız mı? & 800 & \\
\hline $\begin{array}{l}\text { Yaptığınız hatalar sebep gösterilerek, para (veya herhangi maddi bir yatırım) } \\
\text { cezası verildi mi? }\end{array}$ & ,766 & \\
\hline Disiplin cezası aldınız mı? & 682 & \\
\hline Şahsınıza sözle veya davranışla cinsel imalarda bulundu mu? & 668 & \\
\hline Size verilen işler, yapamadığınız bahane edilerek, alınıp başkasına verildi mi? & ,508 & \\
\hline Faktör 2 - Iş ve kariyer ile ilgili engellemeler & & $\% 10,066$ \\
\hline Sahip olduğunuz yetenekten daha az yetenek gerektiren işler aldınız mı? & ,754 & \\
\hline Anlamsız görevler verildi mi? & ,715 & \\
\hline Gereksiz yere, fazla mesaiye bırakıldınız mı? & 710 & \\
\hline $\begin{array}{l}\text { Fiziksel olarak, görevinizin gerektirdiğinden daha ağır işler yapmaya zorlandı- } \\
\text { nız mı? }\end{array}$ & 679 & \\
\hline İstenmeyen, zor işlerin size verildiği oldu mu? & 672 & \\
\hline Çabalarınız karşılığınızı almadığınızıdüşüündüğünüz oldu mu? & 652 & \\
\hline İşinizle ilgili kararlarınıza gereken önemin gösterilmediği oldu mu? & ,617 & \\
\hline Faktör 3 - Tehdit ve taciz & & $\% 5,361$ \\
\hline Toplum önünde yüksek sesle azarlandınız mı? & 700 & \\
\hline Diğer çalışanların sizinle konuşmaları yasaklandı mı? & 691 & \\
\hline Yazılı veya sözlü tehditler aldınız mı? & 674 & \\
\hline $\begin{array}{l}\text { Yönetim kademesinden herhangi birisiyle görüşme isteğiniz / girişiminiz engel- } \\
\text { lendimi }\end{array}$ & 626 & \\
\hline Kötü söz yada küfre maruz kaldınız mı? & 595 & \\
\hline
\end{tabular}




\begin{tabular}{|c|c|}
\hline Üstleriniz, kendinizi rahatça ifade etmenizi engelliyor mu? & ,573 \\
\hline Yaptığınız iş haksız yere eleştirildi mi? & 567 \\
\hline Birlikte çalıștı̆̆ınız kişiler, kendinizi rahatça ifade etmenizi engelliyor mu? & 559 \\
\hline Faktör 4- Özel hayata müdehale & $\% 4,849$ \\
\hline Size sanki akıl hastasıymışsınız gibi davranıldığını düşündünüz mü? & ,708 \\
\hline Utanç verici işleri yapmaya zorlandınız mı? & 694 \\
\hline Dini inançlarınızdan dolayı herhangi bir baskı veya zorlama gördünüz mü? & 679 \\
\hline Siyasi görüşünüzden dolayı herhangi bir baskı veya zorlama gördünüz mü? & 622 \\
\hline Küçük düşürücü isimlerle çağırıldınızmı? & 607 \\
\hline Sizi gülünç duruma düşürmek için bir takım davranışlarınız taklit edildi mi? & 600 \\
\hline Gülünç durumlara düşürüldünüz mü? & 519 \\
\hline Faktör 5 - Işten soğutma & $\% 3,933$ \\
\hline İnsanların arkanızdan kötü konuştuğunu düşündüğünüz oldu mu? & 790 \\
\hline Hakkınızda asılsız söylentilerin ortaya atıldığını düşündüğünüz oldu mu? & ,723 \\
\hline İş arkadaşınız sız orda değilmişsiniz gibi davrandılar mı? & ,596 \\
\hline Siz konuşurken, sebepsiz yere, çevrenizdekilerce sözünüz kesiliyor mu? & 477 \\
\hline Çevrenizdeki insanların sizinle konuşmadıklari oldu mu? & 455 \\
\hline Toplam & $\% 61,771$ \\
\hline
\end{tabular}

Tablo 6'da mobbing değişkenine ilişkin yapılan faktör analizi sonucunda mobbing değişkeninin 5 faktör altında toplanmakta olduğu görülmektedir. Buna göre faktörler bütün olarak mobbing algısının \%61,77'lik oranını açklamaktadır. Faktör analizinde faktör yükü 0,40'ın altında olan değişkenler göz ardı edilmiş, faktörler 7 iterasyon sonucunda birbirine en çok benzeyen değişkenleri faktör haline getiren principal component ile değerlendirilmiş ve varimax döndürme fonksiyonu ile elde edilmiştir.

\section{Bulgular}

Katılımcların örgütsel sessizlik ve mobbing algıladıkları ile iş performansları düzeylerinin cinsiyetlerine göre istatistiksel olarak anlamlı farklılıklar gösterip göstermediğini belirlemek amacıyla t testi yapılmıştır.

Tablo 5a. t Testi (Cinsiyete Göre Fark Analizi)

\begin{tabular}{llllllll}
\hline Değişkenler & Grup & $\mathbf{N}$ & Ortalama & $\begin{array}{l}\text { Standart } \\
\text { Sapma }\end{array}$ & $\mathbf{t}$ & Df & p \\
\hline \multirow{2}{*}{ Iş Performansı } & Erkek & 191 & 3,8010 & 1,01292 &, 302 & 339 &, 763 \\
\cline { 2 - 8 } & Kadın & 150 & 3,7683 &, 96764 & & &, 013 \\
\hline \multirow{2}{*}{$\begin{array}{l}\text { Örgütsel } \\
\text { Sessizlik }\end{array}$} & Erkek & 191 & 3,3410 &, 72990 & 2,487 & 339 &, 593 \\
\hline Kadın & 150 & 3,1311 &, 82632 & & & 339 \\
\hline
\end{tabular}


Yapılan analiz sonuçlarına göre katılımcıların iş performans düzeyleri $(t(339)=, 302 ; p>0,05)$ ve mobbing algıları katılımcların cinsiyetlerine göre farklılaşmamaktadır $(\mathrm{t}(339)=, 537 ; \mathrm{p}>0,05)$. H1a ve $\mathrm{H3a}$ hipotezleri reddedilmiştir. Örgütsel sessizlik algısının ise katılımcların cinsiyetlerine göre farklılaştığı $(\mathrm{t}(339)=2,487 ; \mathrm{p}<0,05)$ bulgusuna ulaşılmıştır. Buna göre erkek katılımclarda (ort=3,34; s.s. =0,72) kadın katılımcilara kıyasla (ort=3,13; s.s.= 0,82 ) örgütsel sessizlik algısının daha yüksek olduğu bulgusuna ulaşılmıştır. H2a hipotezi kabul edilmektedir.(Tablo 7a)

Katılımcıların örgütsel sessizlik ve mobbing algıladıkları ile iş performansları düzeylerinin medeni durumlarına göre istatistiksel olarak anlamlı farklılıklar gösterip göstermediğini belirlemek amacıyla yapılan $t$ testi sonuçları tablo $7 b^{\prime}$ de gösterilmektedir.

Tablo 7b. t Testi (Medeni duruma Göre Fark Analizi)

\begin{tabular}{llllllll}
\hline Değişkenler & Grup & $\mathbf{N}$ & Ortalama & $\begin{array}{l}\text { Standart } \\
\text { Sapma }\end{array}$ & $\mathbf{t}$ & Df & p \\
\hline \multirow{2}{*}{ Iş Performansı } & Evli & 211 & 3,8768 &, 95847 & 2,149 & 339 &, 032 \\
\cline { 2 - 8 } & Bekar & 130 & 3,6404 & 1,03101 & & &, 076 \\
\hline \multirow{2}{*}{$\begin{array}{l}\text { Örgütsel } \\
\text { Sessizlik }\end{array}$} & Evli & 211 & 3,1899 &, 78228 & $-1,780$ & 339 & \\
\hline Mobbing & Bekar & 130 & 3,3441 &, 76876 & & & 0,001 \\
\hline
\end{tabular}

Yapılan analiz sonuçlarına göre katılımcıların mobing algısı $(t(339)=$ $\mathrm{p}>0,05)$. ve iş performansları $(\mathrm{t}(339)=2,149 ; \mathrm{p}<0,05)$. katılımcların medeni durumlarına göre farklılaşmakta olup $\mathbf{H 1} \mathbf{b}$ ve $\mathbf{H 3} \mathbf{b}$ hipotezleri kabul edilmektedir. Evli olan katılımcilarda (ort $=3,87$; s.s. $=0,95$ ) bekar katılımcila$\mathrm{ra}$ (ort= 3,64; s.s. $=1,03$ ) kıyasla iş performanslarının daha yüksek olduğu bulgusuna ulaşılmıştır. Mobbing algısı ise bekar katılımcilarda(ort= 1,93; s.s.= 0,66 ) evli katılımcılara (ort= 1,71 ; s.s. $=0,51$ ) kıyasla daha yüksek olduğu bulgusuna ulaşılmıştır. Fakat örgütsel sessizlik algısı katılımcıların medeni durumlarına göre farklılaşmamaktadır $(t(339)=p>0,05)$. $\mathbf{H} 2 \mathbf{b}$ hipotezi reddedilmektedir.

Katılımcıların örgütsel sessizlik, mobbing algısı ve iş performans düzeylerinin yaşlarına, eğitim seviyelerine ve çalışma sürelerine göre istatistiksel olarak anlamlı farklılıklar gösterip göstermediğini belirlemek amacıyla anova testi kullanılarak analiz edilmiştir.Veriler normal dağılıma uygun olup; örgütsel sessizlik, mobbing algısı ve iş performansı değişkenlerinde homo- 
jenlik sağlanmiş bu sebeple post hoc testlerinden Tukey yöntemi kullanılmiştır.

Tablo 6a. ANOVA (Yaşlara Göre Fark Analizi)

\begin{tabular}{|c|c|c|c|c|c|c|}
\hline \multicolumn{2}{|l|}{ Yaşlarına göre } & $\begin{array}{l}\text { Kareler } \\
\text { toplamı }\end{array}$ & $\begin{array}{l}\text { Df } \\
\text { (Serbestlik derecesi) }\end{array}$ & $\begin{array}{l}\text { Ort.Karesi } \\
\text { Karesi }\end{array}$ & FF & $\begin{array}{c}\mathrm{p} \\
\text { (Önemlilik) }\end{array}$ \\
\hline \multirow{3}{*}{$\begin{array}{l}\text { Iş } \\
\text { Performansı }\end{array}$} & $\begin{array}{l}\text { Gruplar } \\
\text { arasi }\end{array}$ & 15,704 & 4 & 3,926 & 4,137 & ,003 \\
\hline & Grup içi & 318,838 & 336 & ,949 & & \\
\hline & Toplam & 334,542 & & & & \\
\hline \multirow{3}{*}{$\begin{array}{l}\text { Örgütsel } \\
\text { Sessizlik }\end{array}$} & $\begin{array}{l}\text { Gruplar } \\
\text { arası }\end{array}$ & 3,117 & 4 & ,779 & 1,286 & ,275 \\
\hline & Gurup içi & 203,546 & 336 & 606 & & \\
\hline & Toplam & 206,663 & & & & \\
\hline \multirow{3}{*}{ Mobbing } & $\begin{array}{l}\text { Gruplar } \\
\text { arasi }\end{array}$ & 2,415 & 4 & 604 & 1,777 & 133 \\
\hline & Gurup içi & 114,140 & 336 & 340 & & \\
\hline & Toplam & 116,554 & 340 & & & \\
\hline
\end{tabular}

Tablo 8 b'de ise katılımclardan yaş gruplarına göre ölçek ifadelerine verdikleri cevapların ortalama puanı görülmektedir.

Tablo 7b. Katılımcılarnn Yaşlamna göre Tanımlayıcı Istatistik

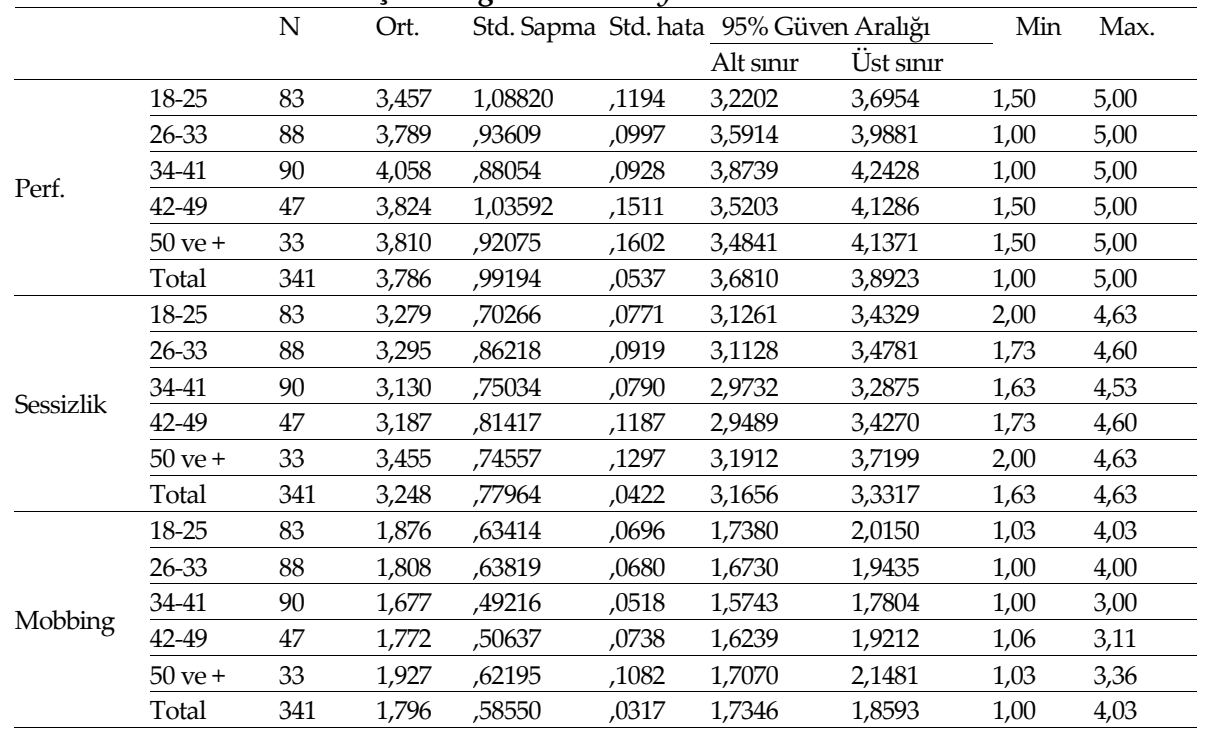


Tablo 8a' de görüldüğü gibi katılımcların iş performans düzeyleri yaşlarına göre farklılaşmaktadır $(F=4,137$ ve $p<0,05)$.

Tablo 8c. TUKEY Testi (Yaşlara Göre)

\begin{tabular}{|c|c|c|c|c|c|c|c|}
\hline \multicolumn{2}{|c|}{ Bağımlı Değiş̧ken (I) YAŞ } & \multirow[t]{2}{*}{ (J) YAŞ } & \multirow[t]{2}{*}{ Ort. Fark (I-J) } & \multirow[t]{2}{*}{ Std. Hata } & \multirow[t]{2}{*}{ Sig. } & \multicolumn{2}{|c|}{ 95\% Güven Aralığ1 } \\
\hline & & & & & & Alt sinir & Üst sinir \\
\hline \multirow{20}{*}{ Performans } & \multirow{4}{*}{$18-25$} & $26-33$ &,- 33194 & 14905 & 172 &,- 7407 & 0769 \\
\hline & & $34-41$ &,$- 60050^{*}$ & ,14824 & 001 & $-1,0071$ &,- 1939 \\
\hline & & $42-49$ &,- 36664 & ,17783 & 239 &,- 8544 & ,1211 \\
\hline & & 50 ve fazla &,- 35277 & ,20047 & ,399 &,- 9026 & 1970 \\
\hline & \multirow{4}{*}{$26-33$} & $18-25$ & ,33194 & , 14905 & 172 &,- 0769 & 7407 \\
\hline & & $\underline{34-41}$ &,- 26856 & ,14604 & ,353 &,- 6691 & ,1320 \\
\hline & & $42-49$ &,- 03470 & ,17599 & 1,000 &,- 5174 & 4480 \\
\hline & & 50 ve fazla &,- 02083 & ,19884 & 1,000 &,- 5662 & ,5245 \\
\hline & \multirow{4}{*}{$34-41$} & $18-25$ & $60050^{*}$ & ,14824 & 001 & 1939 & 1,0071 \\
\hline & & $26-33$ & ,26856 & ,14604 & ,353 &,- 1320 & 6691 \\
\hline & & $42-49$ & 23387 & ,17531 & ,670 &,- 2469 & 7147 \\
\hline & & 50 ve fazla & ,24773 & ,19824 & ,722 &,- 2960 & 7914 \\
\hline & \multirow{4}{*}{$42-49$} & 18-25 & ,36664 & ,17783 & ,239 &,- 1211 & 8544 \\
\hline & & $26-33$ & ,03470 & 17599 & 1,000 &,- 4480 &, 5174 \\
\hline & & $34-41$ &,- 23387 & ,17531 & 670 &,- 7147 & 2469 \\
\hline & & 50 ve fazla & ,01386 & ,22124 & 1,000 &,- 5929 & ,6206 \\
\hline & \multirow{4}{*}{50 ve fazla } & $18-25$ & ,35277 & ,20047 & ,399 &,- 1970 & ,9026 \\
\hline & & $26-33$ & ,02083 & ,19884 & 1,000 &,- 5245 & ,5662 \\
\hline & & 34-41 &,- 24773 & ,19824 & ,722 &,- 7914 & ,2960 \\
\hline & & $42-49$ &,- 01386 & ,22124 & 1,000 &,- 6206 & ,5929 \\
\hline \multirow{20}{*}{ Sessizlik } & \multirow{4}{*}{$18-25$} & $26-33$ &,- 01594 & 11909 & 1,000 &,- 3426 & ,3107 \\
\hline & & $34-41$ & 14915 & ,11845 & ,716 &,- 1757 & 4740 \\
\hline & & $42-49$ & ,09157 & ,14208 & ,968 &,- 2981 & ,4813 \\
\hline & & 50 ve fazla &,- 17604 & ,16018 & 807 &,- 6153 & ,2633 \\
\hline & \multirow{4}{*}{$26-33$} & $\underline{18-25}$ & ,01594 & 11909 & 1,000 &,- 3107 & ,3426 \\
\hline & & $34-41$ & 16508 & ,11668 & 619 &,- 1549 & ,4851 \\
\hline & & $42-49$ & 10751 & ,14062 & ,941 &,- 2782 & ,4932 \\
\hline & & 50 ve fazla &,- 16010 & ,15888 & 852 &,- 5958 & ,2756 \\
\hline & \multirow{4}{*}{$34-41$} & 18-25 &,- 14915 & ,11845 & 716 &,- 4740 & 1757 \\
\hline & & $26-33$ &,- 16508 & ,11668 & 619 &,- 4851 & 1549 \\
\hline & & $42-49$ &,- 05757 & ,14007 & ,994 &,- 4417 & ,3266 \\
\hline & & 50 ve fazla &,- 32519 & ,15839 & ,243 &,- 7596 & 1092 \\
\hline & \multirow{4}{*}{$42-49$} & 18-25 &,- 09157 & ,14208 & ,968 &,- 4813 & 2981 \\
\hline & & $26-33$ &,- 10751 & ,14062 & ,941 &,- 4932 & ,2782 \\
\hline & & 34-41 & ,05757 & ,14007 & ,994 &,- 3266 & ,4417 \\
\hline & & 50 ve fazla & -26761 & 17677 & ,554 &,- 7524 & ,2172 \\
\hline & \multirow{4}{*}{50 ve fazla } & 18-25 & ,17604 & ,16018 & 807 &,- 2633 & 6153 \\
\hline & & $26-33$ & ,16010 & ,15888 & 852 &,- 2756 & ,5958 \\
\hline & & 34-41 & 32519 & ,15839 & ,243 &,- 1092 & ,7596 \\
\hline & & $42-49$ & ,26761 & ,17677 & ,554 &,- 2172 & ,7524 \\
\hline
\end{tabular}




\begin{tabular}{|c|c|c|c|c|c|c|c|}
\hline \multirow{20}{*}{ Mobbing } & \multirow{4}{*}{$18-25$} & $26-33$ & ,06824 & ,08918 & 940 &,- 1764 & ,3128 \\
\hline & & $34-41$ & 19915 & , 08870 & ,166 &,- 0441 & ,4424 \\
\hline & & $42-49$ & 10395 & , 10640 & 865 &,- 1879 & ,3958 \\
\hline & & 50 ve fazla &,- 05104 & 11994 & ,993 &,- 3800 & ,2779 \\
\hline & \multirow{4}{*}{$26-33$} & $18-25$ &,- 06824 & ,08918 & ,940 &,- 3128 & , 1764 \\
\hline & & $34-41$ & 13092 & ,08738 &, 564 &,- 1087 & ,3706 \\
\hline & & $42-49$ & ,03572 & , 10530 & ,997 &,- 2531 & ,3245 \\
\hline & & 50 ve fazla &,- 11928 & ,11897 & 854 &,- 4456 & ,2070 \\
\hline & \multirow{4}{*}{$34-41$} & 18-25 & -,19915 & ,08870 & , 166 &,- 4424 &, 0441 \\
\hline & & $26-33$ & -13092 & , 08738 &, 564 &,- 3706 & 1087 \\
\hline & & $42-49$ &,- 09520 & ,10489 & 894 &,- 3829 & ,1925 \\
\hline & & 50 ve fazla &,- 25019 & ,11861 & ,218 &,- 5755 &, 0751 \\
\hline & \multirow{4}{*}{$42-49$} & $18-25$ &,- 10395 & ,10640 & ,865 &,- 3958 & , 1879 \\
\hline & & $26-33$ &,- 03572 & , 10530 & ,997 &,- 3245 & ,2531 \\
\hline & & $34-41$ & ,09520 & ,10489 & 894 & -1925 & ,3829 \\
\hline & & 50 ve fazla &,- 15499 & ,13237 & ,768 &,- 5180 & ,2080 \\
\hline & \multirow{4}{*}{50 ve fazla } & 18-25 & ,05104 & 11994 & ,993 &,- 2779 & ,3800 \\
\hline & & $26-33$ & 11928 & ,11897 & 854 &,- 2070 & ,4456 \\
\hline & & $34-41$ & 25019 & ,11861 & 218 &,- 0751 &, 5755 \\
\hline & & $42-49$ & 15499 & ,13237 & ,768 &,- 2080 &, 5180 \\
\hline
\end{tabular}

*. Ortalama fark 0,05 düzeyinde anlamlıdır.

Yapılan Tukey testi sonucu ise Tablo 8'de görülmekte olup, bu sonuçlara göre 18-25 yaş aralığında bulunan katılımcıların 34-41 yaşlarındaki katılımc1lara göre daha düşük iş performans düzeyinde olduğu görülmektedir. Cevap ortalamaların farkı ise ,600 olarak tespit edilmiştir. Bu sonuçlara istinaden $\mathbf{H 3 c}$ hipotezi kabul edilmektedir.

Örgütsel sessizlik algısı katılımcıların yaşlarına göre farklılaşmamaktadır ( $\mathrm{F}=1,286$ p >0,05). H2c hipotezi reddedilmektedir. Mobbing alg1sı da katılımcıların yaşlarına göre farklılaşmamaktadır $(\mathrm{F}=1,777 \mathrm{p}>0,05)$. Bu nedenle H1c hipotezi de reddedilmektedir.

Tablo 9a. ANOVA (Ĕ̈itim Durumlarna Göre Fark Analizi)

\begin{tabular}{|c|c|c|c|c|c|c|}
\hline \multicolumn{2}{|c|}{ Eğitim Durumlarına göre } & \multirow{2}{*}{\begin{tabular}{|l|}
$\begin{array}{l}\text { Kareler } \\
\text { toplamı }\end{array}$ \\
24,268
\end{tabular}} & \multirow{2}{*}{$\begin{array}{l}\text { Df } \\
\text { (Serbestlik derecesi) } \\
4 \\
\end{array}$} & \multirow{2}{*}{$\begin{array}{l}\text { Ort.Karesi } \\
6,067 \\
\end{array}$} & \multirow{2}{*}{$\begin{array}{l}\mathbf{F} \\
6,570 \\
\end{array}$} & \multirow{2}{*}{$\begin{array}{l}\mathbf{p} \\
, 000\end{array}$} \\
\hline Iş & Gruplar arası & & & & & \\
\hline Performansı & Gurup içi & 310,274 & 336 & ,923 & & \\
\hline & Toplam & 334,542 & 340 & & & \\
\hline \multirow{3}{*}{$\begin{array}{l}\text { Örgütsel } \\
\text { Sessizlik }\end{array}$} & Gruplar arası & 5,458 & 4 & 1,365 & 2,279 & ,061 \\
\hline & Gurup içi & 201,205 & 36 &, 599 & & \\
\hline & Toplam & 206,663 & 340 & & & \\
\hline \multirow[t]{3}{*}{ Mobbing } & Gruplar arası & ,440 & 4 & ,110 & ,318 & 866 \\
\hline & Gurup içi & 116,114 & 336 & ,346 & & \\
\hline & Toplam & 116,554 & 340 & & & \\
\hline
\end{tabular}


Tablo 9a' da görüldüğü gibi katılımcların iş performans düzeyleri katılımcların eğitim seviyelerine göre farklılaşmaktadır ( $F=6,570$ ve $\mathrm{p}<0,05)$.

Tablo 9b. Katılımcıların Ĕ̈itim Durumlarnna Göre Tanımlayıcı Istatistik

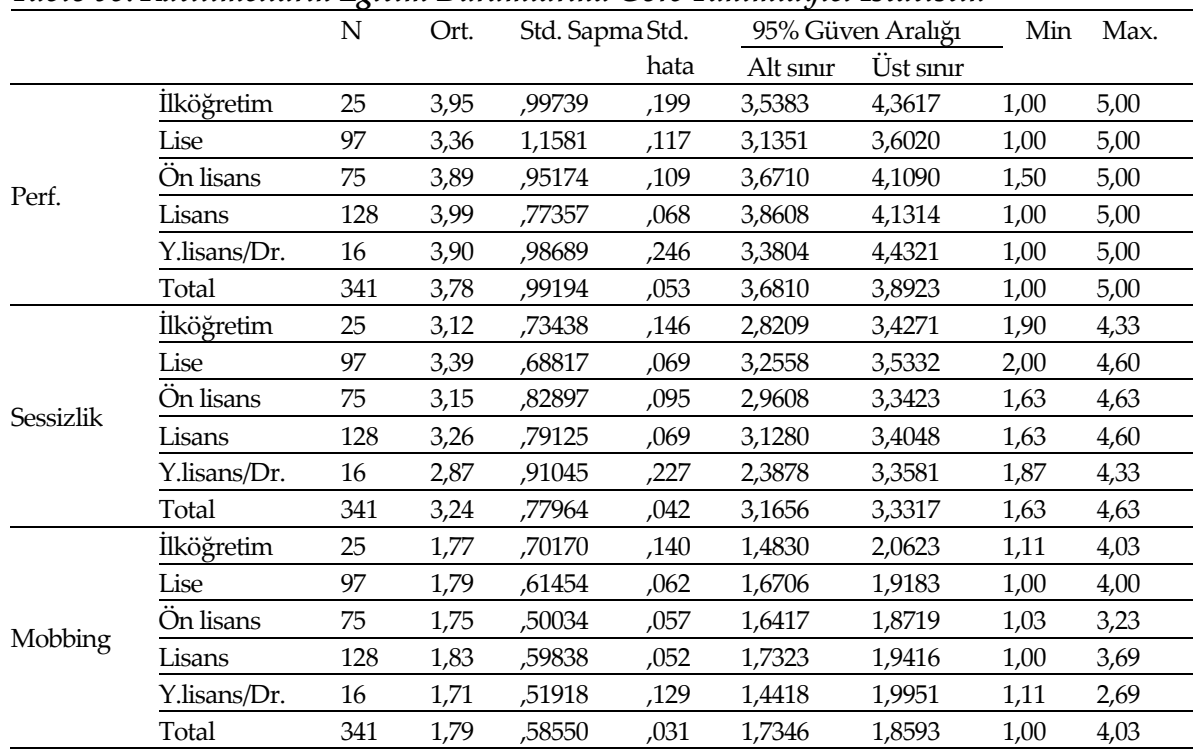

Tablo 9 b'de ise katılımclardan eğitim durumlarına göre ölçek ifadelerine verdikleri cevapların ortalama puanı görülmektedir.

Yapılan Tukey testi sonucuna göre lise mezunu katılımcların iş performans düzeyleri ön lisans ve lisans mezun katılımcılara kıyasla daha düşük düzeydedir. H3d hipotezi kabul edilmektedir.

Örgütsel sessizlik algısı katılımcıların eğitim seviyelerine göre farklılaşmamaktadır $(\mathrm{F}=2,279 \mathrm{p}>0,05)$. Tablo $9 \mathrm{c}^{\prime}$ de verilen test sonuçlarına göre Mobbing algısı da katılımcıların eğitim seviyelerine göre farklılaşmamakta$\operatorname{dir}(\mathrm{F}=, 318 \mathrm{p}>0,05)$. $\mathbf{H} \mathbf{d}$ ve $\mathbf{H 3 d}$ hipotezleri reddedilmiştir. 
Tablo 9c. TUKEY Testi (Eğitim Durumlarna Göre)

\begin{tabular}{|c|c|c|c|c|c|c|c|c|c|}
\hline \multirow{2}{*}{$\begin{array}{l}\text { Bağımlı } \\
\text { Değişken }\end{array}$} & \multirow[t]{2}{*}{ (I) Eğt.Dur. } & \multirow[t]{2}{*}{ (J) Eğt.Dur. } & \multirow{2}{*}{$\begin{array}{l}\text { Ort. Fark } \\
(\mathrm{I}-\mathrm{J})\end{array}$} & \multirow{2}{*}{$\begin{array}{l}\text { Std. } \\
\text { Hata }\end{array}$} & \multirow[t]{2}{*}{ Sig. } & \multicolumn{2}{|c|}{ 95\% Güven Aralığı } & \multirow[t]{2}{*}{ Min. } & \multirow[b]{2}{*}{ Max. } \\
\hline & & & & & & Alt sinur & Üst sınır & & \\
\hline \multirow{20}{*}{ Perfor. } & \multirow{4}{*}{ Ilköğretim } & Lise & ,58144 & ,215 & 056 &,- 0097 & 1,172 & 1,00 & 5,00 \\
\hline & & Ön lisans & ,06000 & ,221 & ,999 &,- 5487 & 6687 & 1,00 & 5,00 \\
\hline & & Lisans &,- 04609 & ,210 & ,999 &,- 6224 &, 5302 & 1,50 & 5,00 \\
\hline & & Y.Lisans/Dr & ,04375 & ,307 & 1,00 &,- 8000 & 8875 & 1,00 & 5,00 \\
\hline & \multirow{4}{*}{ Lise } & Lise &,- 58144 & ,215 &, 056 & ,1726 &, 0097 & 1,00 & 5,00 \\
\hline & & Ön lisans & $-52144^{*}$ & 147 & ,004 &,- 9267 &,- 1162 & 1,00 & 5,00 \\
\hline & & Lisans & $-62754^{*}$ & ,129 & ,000 &,- 9823 &,- 2727 & 1,90 & 4,33 \\
\hline & & Y.Lisans/Dr &,- 53769 & ,259 & ,234 &,- 2489 & ,1735 & 2,00 & 4,60 \\
\hline & \multirow{4}{*}{ Ön lisans } & ilköğretim &,- 06000 & ,221 & ,999 &,- 6687 &, 5487 & 1,63 & 4,63 \\
\hline & & lise &, $52144^{*}$ & 147 &, 004 & 1162 & ,9267 & 1,63 & 4,60 \\
\hline & & $\underline{\text { lisans }}$ &,- 10609 & ,139 & ,942 &,- 4893 & ,2772 & 1,87 & 4,33 \\
\hline & & Y.Lisans/Dr &,- 01625 & ,264 & 1,00 &,- 7420 & ,7095 & 1,63 & 4,63 \\
\hline & \multirow{4}{*}{ Lisans } & Ilköğretim & ,04609 & ,210 & ,999 &,- 5302 & ,6224 & 1,11 & 4,03 \\
\hline & & Lise & $62754^{*}$ & ,129 &, 000 & ,2727 & ,9823 & 1,00 & 4,00 \\
\hline & & Ön lisans & ,10609 & ,139 & ,942 &,- 2772 & 4893 & 1,03 & 3,23 \\
\hline & & Y.Lisans/Dr & ,08984 & ,254 & ,997 &,- 6090 & ,7887 & 1,00 & 3,69 \\
\hline & \multirow{4}{*}{ Y.Lisans/Dr } & Ilköğretim &,- 04375 & ,307 & 1,00 &,- 8875 & 8000 & 1,11 & 2,69 \\
\hline & & Lise & ,53769 & ,259 & ,234 &,- 1735 & 1,248 & 1,00 & 4,03 \\
\hline & & Ön lisans & ,01625 & ,264 & 1,00 &,- 7095 & ,7420 & 1,00 & 5,00 \\
\hline & & Lisans &,- 08984 & ,254 & ,997 &,- 7887 & 6090 & 1,00 & 5,00 \\
\hline \multirow{20}{*}{ Sessizlik } & \multirow{4}{*}{ Ilköğretim } & Lise &,- 27050 & ,173 &, 525 &,- 7465 & ,2055 & 1,50 & 5,00 \\
\hline & & Ön lisans &,- 02756 & ,178 & 1,00 &,- 5177 & ,4626 & 1,00 & 5,00 \\
\hline & & Lisans &,- 14241 & ,169 & ,917 &,- 6065 & ,3217 & 1,00 & 5,00 \\
\hline & & Y.Lisans/Dr & ,25108 & ,247 &, 849 &,- 4284 & ,9306 & 1,00 & 5,00 \\
\hline & \multirow{4}{*}{ Lise } & Ilköğretim & ,27050 & ,173 &, 525 &,- 2055 & ,7465 & 1,90 & 4,33 \\
\hline & & Ön lisans & ,24295 & ,118 & ,248 &,- 0834 &, 5693 & 2,00 & 4,60 \\
\hline & & Lisans & ,12810 & ,104 & ,734 &,- 1576 & ,4138 & 1,63 & 4,63 \\
\hline & & Y.Lisans/Dr & ,52159 & ,208 & ,094 &,- 0511 & 1,094 & 1,63 & 4,60 \\
\hline & \multirow{4}{*}{ Ön lisans } & Ilköğretim & ,02756 & ,178 & 1,00 &,- 4626 &, 5177 & 1,87 & 4,33 \\
\hline & & Lise &,- 24295 & ,118 & ,248 &,- 5693 & ,0834 & 1,63 & 4,63 \\
\hline & & Lisans &,- 11485 & ,112 & 846 &,- 4235 & 1938 & 1,11 & 4,03 \\
\hline & & Y.Lisans/Dr & ,27864 & ,213 & 687 &,- 3058 & ,8631 & 1,00 & 4,00 \\
\hline & & Ilköğretim & ,14241 & ,169 & ,917 &,- 3217 & ,6065 & 1,03 & 3,23 \\
\hline & Lisans & Lise &,- 12810 & ,104 & ,734 &,- 4138 & ,1576 & 1,00 & 3,69 \\
\hline & Lisants & Ön lisans & ,11485 & ,112 & 846 &,- 1938 & ,4235 & 1,11 & 2,69 \\
\hline & & Y.Lisans/Dr & ,39349 & ,205 & ,310 &,- 1693 & ,9563 & 1,00 & 4,03 \\
\hline & & Ilköğretim &,- 25108 & ,247 &, 849 &,- 9306 &, 4284 & 1,00 & 5,00 \\
\hline & YLisans/Dr & Lise &,- 52159 & ,208 & ,094 &,- 0943 & 0511 & 1,00 & 5,00 \\
\hline & 1.Lisalis/DI & Ön lisans &,- 27864 & ,213 & 687 &,- 8631 & ,3058 & 1,50 & 5,00 \\
\hline & & Lisans &,- 39349 & ,205 & ,310 &,- 9563 & ,1693 & 1,00 & 5,00 \\
\hline & & Lise &,- 02178 & ,131 & 1,00 &,- 3834 & ,3399 & 1,00 & 5,00 \\
\hline & Пlköŏretim & Ön lisans & ,01584 & ,135 & 1,00 &,- 3565 & ,3882 & 1,00 & 5,00 \\
\hline & оловтешт & Lisans &,- 06430 & ,128 & ,987 &,- 4168 & ,2882 & 1,90 & 4,33 \\
\hline Mobbing & & Y.Lisans/Dr & ,05423 & ,188 & ,998 &,- 4620 & ,5704 & 2,00 & 4,60 \\
\hline Hoverits & & Ilköğretim & ,02178 & ,131 & 1,00 &,- 3399 & ,3834 & 1,63 & 4,63 \\
\hline & Jise & Ön lisans & ,03762 & ,090 & ,994 &,- 2103 & 2855 & 1,63 & 4,60 \\
\hline & Lise & Lisans &,- 04252 & ,079 & ,983 &,- 2596 & 1745 & 1,87 & 4,33 \\
\hline & & Y.Lisans/Dr &, 07601 & ,158 & ,989 &,- 3590 &, 5111 & 1,63 & 4,63 \\
\hline
\end{tabular}


Polat Yücekaya- Özkan İmamoğlu

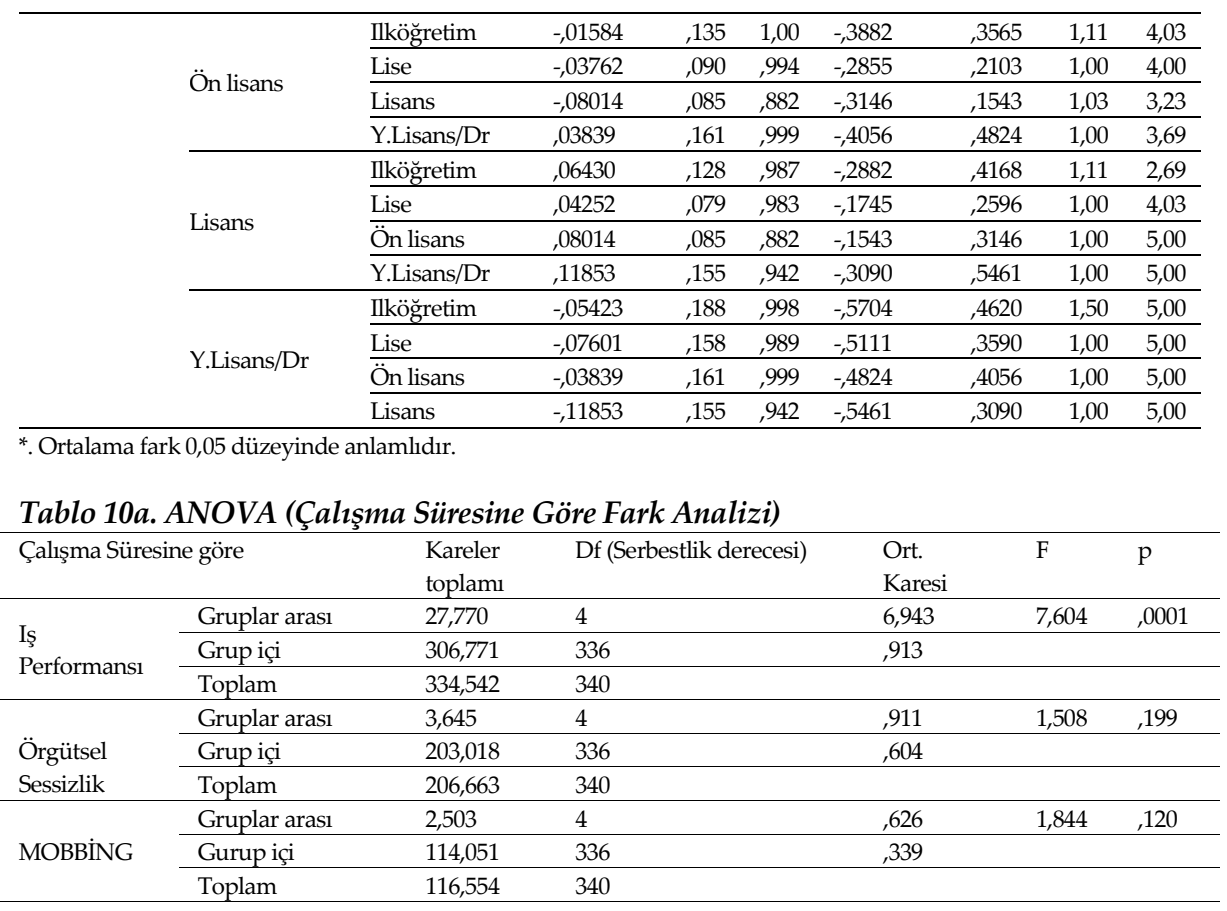

Tablo 10a' de görüldüğü gibi katılmcların iş performans düzeyleri çalışma süresine göre farklılaşmaktadır. ( $F=7,604$ ve $p<0,05)$.

Tablo 10b. Katılımcıların Çalışma Süresine Göre Tanımlayıcı Istatistik

\begin{tabular}{|c|c|c|c|c|c|c|c|c|c|}
\hline & & \multirow[t]{2}{*}{$\mathrm{N}$} & \multirow[t]{2}{*}{ Ort. } & \multirow{2}{*}{\multicolumn{2}{|c|}{ Std. Sapma Std. Hata }} & \multicolumn{2}{|c|}{ 95\% Güven aralığı } & \multirow[t]{2}{*}{ Min. } & \multirow[t]{2}{*}{ Max. } \\
\hline & & & & & & Alt sinır & Üst sinır & & \\
\hline \multirow{6}{*}{ Perf. } & $1-4$ yil & 81 & 3,36 & 1,026 & , 1140 & 3,1342 & 3,5880 & 1,00 & 5,00 \\
\hline & 5-10 yıl & 93 & 3,93 & 1,044 & , 1083 & 3,7177 & 4,1479 & 1,00 & 5,00 \\
\hline & $11-16$ yil & 58 & 4,03 & 6411 & 0841 & 3,8659 & 4,2031 & 2,75 & 5,00 \\
\hline & $17-22$ yıl & 61 & 4,07 & ,7207 & ,0922 & 3,8892 & 4,2584 & 1,00 & 5,00 \\
\hline & $23 \mathrm{yll} v e+$ & 48 & 3,55 & 1,198 & , 1730 & 3,2092 & 3,9053 & 1,50 & 5,00 \\
\hline & Total & 341 & 3,78 & ,9919 & 0537 & 3,6810 & 3,8923 & 1,00 & 5,00 \\
\hline \multirow{6}{*}{ Sessizlik } & $1-4 \mathrm{yll}$ & 81 & 3,27 & ,7892 & 0876 & 3,1028 & 3,4519 & 1,73 & 4,63 \\
\hline & 5-10 yıl & 93 & 3,19 & 8369 & 0867 & 3,0201 & 3,3648 & 1,73 & 4,60 \\
\hline & $11-16$ yıl & 58 & 3,07 & ,7254 & ,0952 & 2,8846 & 3,2660 & 1,63 & 4,53 \\
\hline & $17-22 \mathrm{yll}$ & 61 & 3,36 & ,7608 & 0974 & 3,1729 & 3,5626 & 1,73 & 4,60 \\
\hline & 23 yll ve + & 48 & 3,36 & ,7147 & , 1031 & 3,1598 & 3,5749 & 1,73 & 4,60 \\
\hline & Total & 341 & 3,24 & ,7796 & ,0422 & 3,1656 & 3,3317 & 1,63 & 4,63 \\
\hline \multirow{6}{*}{ Mobbing } & $1-4$ yll & 81 & 1,94 & ,6795 & ,0755 & 1,7928 & 2,0933 & 1,03 & 4,03 \\
\hline & 5-10 yıl & 93 & 1,73 & ,5994 & ,0621 & 1,6069 & 1,8538 & 1,00 & 4,00 \\
\hline & $11-16$ yıl & 58 & 1,72 & ,5058 & ,0664 & 1,5958 & 1,8618 & 1,08 & 3,00 \\
\hline & $17-22$ yıl & 61 & 1,75 & ,5313 & , 0680 & 1,6236 & 1,8958 & 1,00 & 3,39 \\
\hline & 23 yll ve + & 48 & 1,80 & ,5162 & ,0745 & 1,6591 & 1,9589 & 1,11 & 2,83 \\
\hline & Total & 341 & 1,79 &, 5855 & 0317 & 1,7346 & 1,8593 & 1,00 & 4,03 \\
\hline
\end{tabular}


Tablo 10 b' de ise katılımclardan çalışma sürelerine göre ölçek ifadelerine verdikleri cevapların ortalama puanı görülmektedir.

Tablo 10c. Tamhane Testi (Katılımcıların Çalışma Süresine Göre)

\begin{tabular}{|c|c|c|c|c|c|c|c|}
\hline \multirow[t]{2}{*}{ Bağımlı değişken } & \multirow[t]{2}{*}{ (I) Çalışma süresi } & \multirow{2}{*}{$\begin{array}{l}\text { (J)çalışma } \\
\text { süresi }\end{array}$} & \multirow{2}{*}{$\begin{array}{l}\text { Ort. } \\
\text { Fark1 (I-J) }\end{array}$} & \multirow{2}{*}{\multicolumn{2}{|c|}{ Std. Hata P. }} & \multicolumn{2}{|c|}{ 95\% Güven aralığı } \\
\hline & & & & & & Alt sinur & Üst sinur \\
\hline \multirow{20}{*}{ Performans } & \multirow{4}{*}{$1-4$ yıl } & 5-10 yıl &,$- 57168^{*}$ & ,1572 &, 004 & $-1,0178$ &,- 1256 \\
\hline & & $11-16$ yil &,$- 67337^{+}$ & 1417 & ,000 & $-1,0768$ &,- 2700 \\
\hline & & $17-22$ yil &,$- 71266^{*}$ & , 1466 &, 000 & $-1,1299$ &,- 2954 \\
\hline & & 23 yll ve + &,- 19618 & ,2072 & 986 &,- 7914 & ,3990 \\
\hline & \multirow{4}{*}{$5-10$ yıl } & $1-4$ yıl &, $57168^{+}$ & 1572 & ,004 & ,1256 & 1,0178 \\
\hline & & $11-16$ yıl &,- 10169 & ,1371 & ,998 &,- 4915 & ,2882 \\
\hline & & $17-22$ yıl &,- 14097 & ,1423 & ,980 &,- 5452 & 2633 \\
\hline & & 23 yll ve + & 37550 & 2041 & ,513 &,- 2113 & ,9623 \\
\hline & \multirow{4}{*}{$11-16$ yil } & $1-4$ yil & $67337^{*}$ & , 1417 &, 000 & ,2700 & 1,0768 \\
\hline & & 5-10 yll & , 10169 & ,1371 & ,998 &,- 2882 & 4915 \\
\hline & & $17-22$ yil &,- 03929 & , 1249 & 1,000 &,- 3957 & ,3172 \\
\hline & & 23 yll ve + & 47719 & ,1924 & , 145 &,- 0793 & 1,0337 \\
\hline & \multirow{4}{*}{$17-22$ yll } & $1-4$ yil & ,71266 & 1466 & ,000 & 2954 & 1,1299 \\
\hline & & 5-10 yl & 14097 & , 1423 & ,980 &,- 2633 &, 5452 \\
\hline & & $11-16$ yıl & 03929 & ,1249 & 1,000 &,- 3172 & ,3957 \\
\hline & & 23 yll ve + & ,51648 & ,1960 & ,098 &,- 0496 & 1,0826 \\
\hline & \multirow{4}{*}{23 yll ve + } & $1-4$ yıl & 19618 & ,2072 & ,986 &,- 3990 & ,7914 \\
\hline & & 5-10 yl &,- 37550 & ,2041 &, 513 &,- 9623 & 2113 \\
\hline & & $11-16$ yıl &,- 47719 & 1924 & , 145 & $-1,0337$ & ,0793 \\
\hline & & $17-22$ yil &,- 51648 & ,1960 & ,098 & $-1,0826$ & ,0496 \\
\hline \multirow{20}{*}{ Sessizlik } & \multirow{4}{*}{$1-4$ yll } & 5-10 yıl & ,08489 & ,1233 & ,999 &,- 2650 & 4348 \\
\hline & & $11-16$ yıl & 20208 & ,1294 & ,725 &,- 1667 &, 5709 \\
\hline & & $17-22$ yıl &,- 09039 & ,1310 & ,999 &,- 4636 & ,2828 \\
\hline & & 23 yll ve + &,- 08999 & ,1354 & ,999 &,- 4771 & 2971 \\
\hline & \multirow{4}{*}{ 5-10 yıl } & $1-4$ yil &,- 08489 & , 1233 & ,999 &,- 4348 & 2650 \\
\hline & & $11-16$ yıl & ,11719 & ,1288 & ,989 &,- 2496 &, 4840 \\
\hline & & $17-22$ yil &,- 17529 & ,1304 & 865 &,- 5465 & 1960 \\
\hline & & 23 yll ve + &,- 17489 & ,1348 & 889 &,- 5601 & ,2103 \\
\hline & \multirow{4}{*}{$11-16$ yll } & $1-4$ yil &,- 20208 & ,1294 & ,725 &,- 5709 & 1667 \\
\hline & & 5-10 yıl &,- 11719 & , 1288 & ,989 &,- 4840 & 2496 \\
\hline & & $17-22$ yll &,- 29247 & ,1362 & ,292 &,- 6812 &, 0963 \\
\hline & & 23 yll ve + &,- 29207 & ,1404 & ,335 &,- 6940 & ,1098 \\
\hline & \multirow{4}{*}{$17-22$ yıl } & $1-4$ yıl & ,09039 & ,1310 & ,999 &,- 2828 & 4636 \\
\hline & & 5-10 yıl & ,17529 & ,1304 & ,865 &,- 1960 & ,5465 \\
\hline & & $11-16$ yıl & 29247 & ,1362 & ,292 &,- 0963 & 6812 \\
\hline & & 23 yll ve + & , 00040 & , 1418 & 1,000 &,- 4055 & 4063 \\
\hline & \multirow{4}{*}{23 yil ve + } & $1-4$ yil & 08999 & ,1354 & 999 &,- 2971 & ,4771 \\
\hline & & 5-10 yıl & ,17489 & ,1348 & 889 &,- 2103 & ,5601 \\
\hline & & $11-16$ yıl & 29207 & ,1404 & ,335 &,- 1098 & ,6940 \\
\hline & & $17-22$ yıl &,- 00040 & , 1418 & 1,000 &,- 4063 & 4055 \\
\hline \multirow{4}{*}{ Mobbing } & \multirow{4}{*}{$1-4$ yıl } & 5-10 yıl & ,21273 & ,0978 & 271 &,- 0649 & 4903 \\
\hline & & $11-16$ yıl & ,21427 & 1005 & 299 &,- 0719 & 5004 \\
\hline & & $17-22 \mathrm{yll}$ & , 18341 & ,1016 & ,533 &,- 1057 & 4725 \\
\hline & & 23 yll ve + & 13403 & 1060 & 904 &,- 1686 & 4366 \\
\hline
\end{tabular}




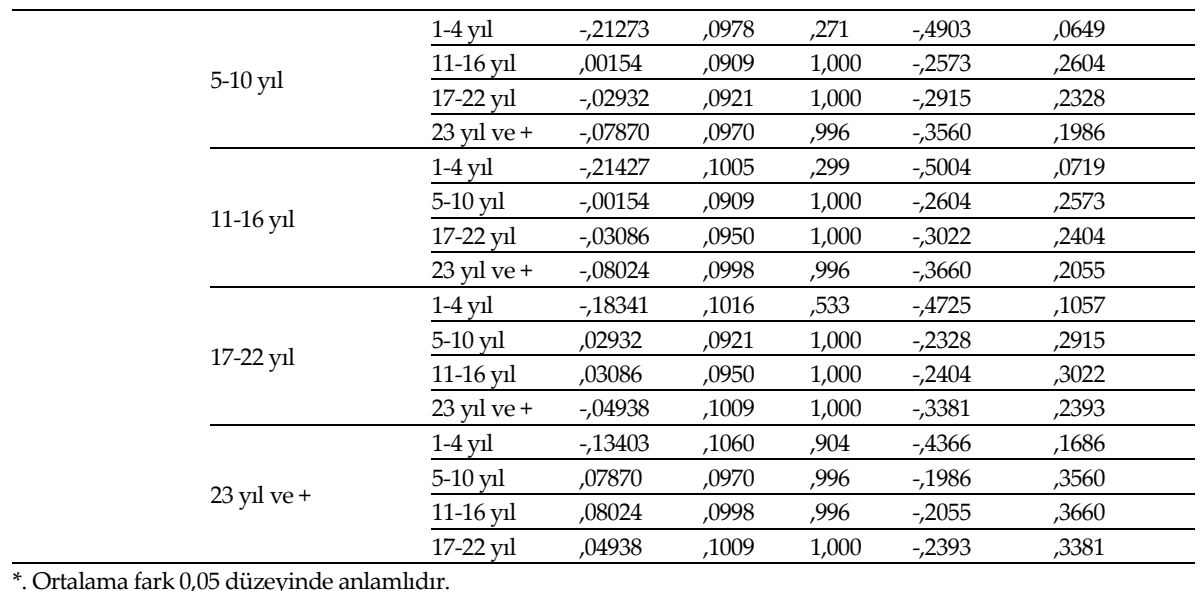

Varyansların homojenliği koşulu sağlanamadığı için Tamhane testi yapılmış olup test sonucuna göre; çalışma süresi 1-4 yıl olanlar ile 6-10, 11-16, 17-22 yıl çalışma süresi olan katılımcıların performans düzeyleri farklıdır. En düşük performans düzeyine sahip katılımcıların 1-5 yıl arası çalışma süresindeki katılımcılar olduğu bulgusuna ulaşılmıştır. H3e hipotezi kabul edilmektedir. Katılımcların örgütsel sessizlik algılari çalışma süresine göre farklılaşmamaktadır ( $\mathrm{F}=1,508$ ve $\mathrm{p}>0,05)$. H2e hipotezi reddedilmektedir. Katılımcların mobbing algısı da çalışma süresine göre farklılaşmamaktadır $(\mathrm{F}=1,844 \mathrm{p}>0,05)$. H1e hipotezi reddedilmektedir.

Tablo 11. Regresyon Analizi (Örgütsel sessizlik, Mobbing ve Iş performansı)

\begin{tabular}{|c|c|c|c|c|c|c|c|c|}
\hline $\begin{array}{l}\text { Bağımsız } \\
\text { Değişken }\end{array}$ & $\begin{array}{l}\text { Bağımlı } \\
\text { Değişken }\end{array}$ & $\mathbf{R}^{2}$ & B & Std.Hata & $t$ & $\mathbf{P}$ & $\beta$ & F \\
\hline $\begin{array}{l}\text { Örgütsel } \\
\text { Sessizlik }\end{array}$ & Iş Performansı & ,046 & 273 & ,067 & 4,051 & 0001 & -215 & 16,410 \\
\hline Mobbing & Iş Performansı & 075 & 159 & ,027 & 5,910 & ,0001 &,- 275 & 34,260 \\
\hline
\end{tabular}

Tablo 9'daki regresyon analizi sonucuna göre bağımlı değişken olan iş performansı düzeyini örgütsel sessizlik etkilemekte olup $\left(R=, 215, R^{2}=, 046\right.$, $\mathrm{F}=16,410 \mathrm{P}<0,01$ ), benzer şekilde mobbing de iş performansını etkilemekte$\operatorname{dir}\left(\mathrm{R}=, 159, \mathrm{R}^{2}=, 075, \mathrm{~F}=34,260 \mathrm{P}<0,01\right) \mathrm{Bu}$ sonuçlara göre $\mathbf{H 4}$ ve $\mathbf{H 5}$ hipotezleri kabul edilmektedir. 


\section{Tartışma ve Sonuç}

$\mathrm{Bu}$ araştırmada mobbing ve örgütsel sessizlik algısının çalışanların iş performansına etkilerini tespit etmeye çalışılmıştır. Araştırma, Çanakkale ilinde görevli 341 kamu çalışanı ile yüz yüze anket uygulaması yapılmak suretiyle veri toplanması ve elde edilen verilerin analiz edilmesi ile gerçekleştirilmiştir. Elde edilen verilerle araştırma hipotezleri test edilmiştir. Yapılan $t$ testi sonuçlarına göre katılımcıların mobbing algılarının cinsiyetlerine göre farklılaşmamakta olduğu tespit edilmiş olup bu sonuç (Furat ve Ceyhan, 2019) çalışması ile uyumludur. Katılımciların iş performans düzeyleri de cinsiyetlerine göre farklılaşmamakta olduğu tespit edilmiştir.

Örgütsel sessizlik algısının ise katılımcıların cinsiyetlerine göre farklılaştığı bulgusuna ulaşılmıştır. Yapılan birçok çalışmada çalışanların cinsiyetinin örgütsel davranış gösterme eğilimlerinde önemli rol oynadığı belirtilmektedir (Gürer ve Deniz, 2018; Britton, 2000; Morrison ve Milliken, 2000). Bu çalışmada erkek katılımclarda örgütsel sessizlik algısının, kadın katılımcllara kıyasla daha yüksek olduğu bulgusuna ulaşılmıştır. Bu sonuç (Çiçek Sağlam ve Yüksel, 2015; Çakıcı, 2010; Pinder ve Harlos, 2001) çalışmaları ile uyumludur. Cinsiyete atfedilen anlam her toplumda ayn olmayıp farklılık göstermektedir (Kutanis ve Çetinel, 2014). Erkek çalışanların genellikle ev geçindirme kaygısı taşımaları ve işlerini kaybetme korkusu yaşamaları, iş ortamında sorun çikaran kişi olarak algılanmak istememeleri gibi nedenlere sessiz kaldıkları değerlendirilmektedir.

Literatürde çalışanların medeni durumunun örgütsel sessizlik algısına etki eden faktörlerden olduğu belirtilmektedir (Gürer ve Deniz, 2018; Yıld1rım ve Çarıkçı, 2017). Fakat bu araştırmada incelenen değişkenlerden örgütsel sessizlik algısının katılımcıların medeni durumlarına göre farklılaşmamakta olduğu tespit edilmiştir. Bu sonuç ise (Şekerli, 2013; Yanık, 2012) çalışmaları ile uyumludur.

Araştırmanın diğer değişkenleri olan mobing algısı ve iş performanslarının katılımcıların medeni durumlarına göre farklılaştığı tespit edilmiştir. Mobbing algısının bekarlar olan çalışanlarda evlilere kıyasla daha yüksek olduğu bulgusuna ulaşılmıştır. Bu durum genç çalışanların işletmede kendilerini önemsiz ve değersiz hissetmeleri sonucu daha alıngan olabildikleri, üstlerinden gelen her ikazı baskı yapılıyormuş gibi algılamalarının bir sonucu olabileceği gibi; üst ve amir pozisyonunda bulunan kişilerin, çalışanların 
evli olmaları dolayısıyla daha saygilı davranmalarının bir sonucu olarak mobbing algısı oluşturacak davranışlardan kaçınmaları durumunda ortaya çıkabilmektedir. Katılımcılardan evli olanların bekarlara kıyasla iş performanslarının ise daha yüksek olduğu bulgusuna ulaşılmıştır. Bu sonuç ise evli çalışanların bakmakla yükümlü olduğu kişiler olması nedeniyle işlerini kaybetme korkusu yaşamaları, yada ailedeki huzur ve düzenli yaşantının işyerine de taşınması gibi nedenlerle ortaya çıkabilmektedir.

Araştırmada incelenen değişkenlerin katılımcıların yaş, eğitim seviyesi ve çalışma sürelerine göre farklılık gösterip göstermediğini tespit etmek amacıyla ANOVA analizleri yapılmıştır. Yapılan analizlerin sonuçlarına göre; Örgütsel sessizlik algısı ve mobbing algısı katılımcıların yaşlarına göre farklılaşmamakta olup, iş performans düzeyleri ise katılımcıların yaşlarına göre farklılaşmaktadır. 18-25 yaş aralığında bulunan katılımcıların 3441 yaşlarındaki katılımclara göre daha düşük iş performans düzeyinde olduğu tespti edilmiştir. Bu sonuç genç çalışanların kariyer için hedef belirlemede kararsız bir dönemde oldukları ve hedefe ulaşmak için daha az çaba harcadıklarını göstermektedir.

Örgütsel sessizlik algısı ve mobbing algısı katılımcıların eğitim seviyelerine göre farklılaşmamaktadır. Fakat araştırmanın bağımlı değişkeni olan iş performansı katılımcıların eğitim seviyelerine göre farklılaşmaktadır. Lise mezunu olan katılımciların performans düzeyleri ön lisans ve lisans mezun katılımcılara kıyasla daha düşük düzeydedir. Bu sonuç üniversite eğitimi almış olan çalışanlarda kariyer yönetimi bağlamında daha üst düzey pozisyonlarda çalışma istek ve arzusu taşımaları nedeniyle yüksek performans gösterdikleri şeklinde yorumlabilmektedir. Oysa düşük eğitim seviyesinde olan çalışanlar için terfi etme umudu yok ise daha fazla performans göstermek için gerekçe de olmayacaktır.

Araştırmanın bir başka sonucu ise katılımcıların çalışma sürelerine göre örgütsel sessizlik, mobbing ve iş performanslarının farklılık gösterip göstermediğine ilişkin yapılan ANOVA analizidir. Katılımcıların örgütsel sessizlik algıları ve mobbing algıları çalışma süresine göre farklılaşmamaktadır. Katılmcıların iş performansları ise çalışma süresine göre farklılık göstermektedir. Çalışma süresi 1-5 yıl olanlar ile 11-16 yıl olanlar ile 17-22 yıl çalı̧̧ma süresindeki katılımclar ile 23 yıl ve daha fazla çalışma süresi olan katılımclların performans düzeyleri farklıdır. En düşük performans düzeyine sahip katılımcıların 1-5 yıl arası çalışma süresindeki katılımcılar olduğu bulgusu- 
na ulaşılmıştır. 11-16 yıllık çalışma süresine sahip katılımcların iş performansları 1-5 yıl olanlara kıyasla; çalışma süresi 17-22 yıl olan katılımcıların iş performansları ise 23 yıl ve daha fazla çalışma süresi olan katılımcılara nazaran daha yüksektir. Bu sonuç bize iş performansı için konulması gereken kariyer hedeflerinin ne kadar önemli olduğunu göstermektedir. İş yaşamlarının başlarında olan çalışanların düşük performans göstermelerinin pek çok nedeni olabilir. Bunlardan biri hedef yoksunluğu durumu ile açılanabilir. Bu durum çalışma süresi 23 yıldan fazla olan çalışanlar için de geçerli olabilmektedir. Emeklilik beklentisine girmiş olan çalışanlar hem değişen teknolojiye uyum sağlamakta zorlanmakta hem de kariyer haritalarında sona yaklaşmış olmaları neticesinde düşük performans gösterebilmektedirler.

Araştırmada incelenen bağımsız değişkenlerin bağımlı değişken üzerindeki etkisini belirlemek amacıyla yapılan regresyon analizi sonuçlarına göre bağımlı değişken olan iş performansı düzeyini örgütsel sessizlik etkilemektedir $\left(R=-215, R^{2}=, 046, \beta=, 273 F=16,410, p<0,01\right)$. Örgütsel sessizlik ile iş performansı arasında negatif bir korelasyon mevcut olup,örgütsel sessizlikte meydana gelen bir standart sapma miktarı değişim iş performansında 0,273 standart sapma değişime neden olmaktadır. Bu sonuç (Tayfun ve Çatır, 2013) çalışmaları ile uyumludur. Diğer bağımsız değişken olarak araştırmada incelenen mobbing olgusunun da katılımcların iş performansını etkilemekte ( $\left.R=-275, R^{2}=, 075, \beta=, 159 \mathrm{~F}=34,260, \mathrm{p}<0,01\right)$ olduğu tespit edilmiştir. Araştırma sonucuna göre mobbing algısında meydana gelen bir standart sapma miktarı değişim iş performansında 0,159 standart sapma değişime neden olmaktadır. Bu sonuç (Çalış Duman ve Akdemir, 2016) çalışmaları ile de uyumludur.

İşletmelerde mobbing arzu edilmeyen bir durumdur. Çalışan performansı üzerinde olumsuz etkilere neden olmaktadır. Mobbing sadece maruz kalanların etkilendiği bir durum olmayıp, çalışanın ailesine, çevresine, topluma ve hatta ülke ekonomisine de etkilerinin yansıdığ açıdan mobbig kansere benzetilebilir. Eğer durumu değiştirmek için tedbir alınmaz ise organizasyonun en değerli ve hayati parçası olan çalışanlar üzerindeki olumsuz etkisi nedeniyle örgütün bütün süreçlerinde olumsuz etkileri hızla yayılacak ve büyük kayıplara neden olacaktır.

Çalışanların yetenek ve kabiliyetleri işletmelerin sürdürülebilir kara ulaşmalarında büyük öneme sahiptir. Oysa ki, işletmelerde çalışanlara uy- 
gulanan mobbing nedeniyle, yetenekli çalışanların işletme amacına hizmet etme isteğinin azalmasının yanı sıra, işletmeye zarar veren tutum ve davranışlar sergilemelerine neden olmaktadır. Bununla beraber çalışan performansında azalmaya neden olmaktadır. Işletmelerde mobbing davranışlarına asla müsamaha gösterilmemelidir.

Bundan sonraki araştırmacılar için önerimiz, iş performansı üzerinde mobbing, örgütsel sessizlik algısı haricinde etkisi olabilecek başka değişkenlerin (örgüt kültürü, adalet, bağlllık vb.) incelenmesidir. Bu ve benzer araştırmalar, çalışanların iş performansı üzerinde olumlu ve olumsuz etkisi olabilecek değişkenler tespit edilerek yöneticiler için olumsuz etkenleri giderme maksatlı tedbirler alması için rehber niteliğinde olacaktır. 


\title{
EXTENDED ABSTRACT
}

\section{The Effect of Mobbing and Organizational Silence on Job Performance: A Research on Çanakkale Province}

\author{
Polat Yücekaya- Özkan İmamoğlu \\ Çanakkale 18 Mart University University- Amasya University
}

People live in a society; therefore, violence is inevitable in human relations. In working life, it is often observed that employees are physically or psychologically violent to each other. In the Industrial Revolution, while the efforts were made to prevent more physical violence in the workers' work life since they were more physically engaged in work; employees in the information society started to do business with intellectual labor. Therefore, psychological violence is more common in business life. In business life, the consequences of applying psychological violence instead of physical violence may be more severe (Laleoğlu and Özmete, 2013). Mobbing is a situation in which one or more employees in a workplace consistently exhibit repeated negative behaviors to make another employee feel pain, frustration, and grief (Brodsky, 1976). Leymann (1990) describes mobbing as "hostile and unethical" behavior applied to a single individual. Incidents and situations that happen once are not considered as mobbing (Hoel et al., 2001). These behaviors should be repeated frequently, at least once a week, and they should continue for at least six months (Laleoğlu and Özmete, 2013). Mobbing is an emotional attack on an employee. That is, it is "abusive behavior, harassing, injuring, ostracizing, or harming the employee's business" behavior intended to damage the employee's reputation and status at work (Zapf, 1999). Mobbing is negative and constantly repeated behavior (Thylefors, 1987). In addition, there is a power difference between the parties of mobbing (Salin, 2003). When studies about mobbing are examined in the literature, it is observed that the most important effect of mobbing is its negative effect on employee performance (Davenport et al., 2003; Çalış Duman and Akdemir, 2016). It has negative effects not only on individual performance but also on organizational performance (Divincová and Siváková, 2014; Korkmaz et al., 2014; Çınar and Akpunar, 2017). Mobbing reduces job satis- 
faction while destroying employee self-confidence. In addition, mobbing can increase the intention to leave the job, causing employees to change their career plans (Zapf, 1999).

Organizational silence was first used as a concept by Morison and Miliken (2000). In their work, they have described organizational silence as the "active and conscious action"of employees and intentional keeping the information, ideas and thoughts of the employees in the enterprise. When previous studies are examined, the factors that cause silence behavior are expressed as "fears and beliefs" (Miliken et al., 2003; Gardezi et al., 2009), "organizational norms and rules" (Premaux and Bedeian, 2003; Yalçın and Baykal, 2012), "perceived support concept in the organization" (Dyne et al., 2003), and "lack of organizational trust" (Nikolaou et al., 2011). Employees exhibit silence behavior for reasons such as lack of expression of problems, fear prevails in the enterprise, existence of strict rules and norms; and these reasons negatively affects job satisfaction and job performance (Morrison and Milliken 2000; Çakıcı 2010). In addition, it is stated that it increases the intention to quit, prevents the emergence of innovative ideas, reduces the sense of commitment and causes many personal problems on the employee who acts in silence (Vakola and Bouradas, 2005; Premeaux and Bedeian, 2003; Donaghey et al., 2011).

The individual performance of employees is extremely important for businesses. The most valuable resource of enterprises is human resources. A business can only achieve success in line with the performance of its employees (Benligiray, 2004). At a time when competition is increasing, innovation and changes occur very quickly, globalization is experienced in the world and it is easier to access information, businesses have to evaluate their resources in the most effective way. Improving the performance of human resources is the most effective tool in achieving sustainable profits. Performance evaluation criteria should be objective, separate performance of high performance employees and low performance should be adopted, and the principle of frugality, effectiveness and efficiency should be adopted as a management tool (Çevik et al., 2008). It should be taken into consideration that the physical and psychological readiness of the employees is the most important factors in achieving the goals of the business (Yazıcıoglu, 2010).

The purpose of this research is to determine the effects of mobbing and the perception of organizational silence on employees ' job performance. In 
this research, convenience sampling method was used. It is assumed that the sample has a high ability to represent the universe. The assumptions of the research are as follows: The sample is assumed to have high ability to represent the universe. The scales included in the survey are assumed to be suitable for research purposes. It is assumed that the survey participants answered the statements sincerely and accurately. The statistical analysis method used to analyze data is assumed to be appropriate.

This research is limited to scales designed to measure variables of mobbing, organizational silence, and business performance. Participants in the research were limited to public personnel working in Çanakkale. The concepts of mobbing, organizational silence, and work perception, which are discussed in this research, are concepts that can change over time. Therefore, the findings of the study are limited to the time period in which they were applied. Another constraint of research is the fiscal constraint.

In the study, data was collected by applying a questionnaire. For this purpose, data was collected through convenience sampling method in the period covering January February 2019, by conducting face-to-face surveys with 341 public employees working in Çanakkale. Research hypotheses were tested with the obtained data. According to the t-test results, it was determined that the participants' mobbing perceptions did not differ according to their gender and this result is compatible with the study (Firat and Ceyhan, 2019). It was determined that the job performance levels of the participants did not differ according to their gender.

It was determined that the perception of organizational silence differs according to the gender of the participants. In this study, it was found that the perception of organizational silence was higher in male participants compared to female participants. Male employees are generally considered to be silent for reasons such as anxiety for earning a living for their families and fear of losing their jobs, and not wanting to be perceived as a troublemaker in the work environment.

It is stated in the literature that the marital status of employees is one of the factors influencing the perception of organizational silence (Gürer and Deniz, 2018; Yıldırım and Çarıkçı, 2017). However, it was determined that the perception of organizational silence, which is one of the variables examined in this study, does not differ according to the marital status of the par- 
ticipants. This result is compatible with the studies of (Şekerli, 2013; Yanık, 2012).

It has been determined that the perception of mobbing and job performances, which are other variables of the research, differ according to the marital status of the participants. It has been found that mobbing perception is higher in single employees compared to married people. It was found that the married participants had higher job performances compared to the singles.

ANOVA analyzes were conducted to determine whether the variables examined in the study differed according to the age, education level and working time of the participants. According to the results of the analyzes, the perception of organizational silence and mobbing do not differ according to the ages of the participants, while their job performance levels differ according to the ages of the participants. Participants between the ages of 18 and 25 were found to have a lower level of job performance than participants aged 34 to 41 .

The perception of organizational silence and the perception of mobbing are not differentiated according to the participants ' educational levels; however, job performance, which is the dependent variable of the research, differs according to the participants ' level of education. The performance levels of the participants who graduated from high school were lower compared to the participants who graduated from associate degrees and Bachelor's degrees.

Organizational perception of silence and mobbing perceptions of the participants do not differ according to the working time. The job performances of the participants differ according to the working time. There is a difference between the performance levels of those with 1-5 years of working time and the performance levels of those with 11-16 years of working time, between the participants with a working time of 17-22 years and those with 23 years or more. It has been found that the participants with the lowest performance level are the participants with a working time of 1-5 years. The job performances of the participants with 11-16 years of working time are higher than those of 1-5 years. The job performances of the participants with a working time of 17-22 years are higher than those with a working period of 23 years or more. 
According to the results of the regression analysis conducted to determine the effect of the independent variables examined in the research on the dependent variable, organizational silence affects the level of job performance, which is the dependent variable $\left(R=-, 215, R^{2}=, 046, \beta=, 273 F=16,410\right.$, $p<0,01)$. There is a negative correlation between organizational silence and work performance, and a standard deviation amount that occurs in organizational silence causes 0.2273 standard deviation changes in job performance. This result is consistent with the work of (Tayfun and Çatır, 2013). It was determined that the mobbing phenomenon examined in the research as another independent variable also affects the job performance of the participants $\left(R=-, 275, R^{2}=, 075, \beta=, 159 F=34,260, p<0,01\right)$. According to the results of the research, a standard deviation change in mobbing perception causes 0.1159 standard deviation changes in job performance. This result is also compatible with the studies of (Çalış Duman and Akdemir, 2016).

The skills and abilities of the employees are of great importance for the enterprises to reach sustainable profit. However, due to mobbing applied to employees in businesses, the willingness of skilled employees to serve the purpose of the business is reduced and this causes employees to exhibit attitudes and behaviors that harm the business. This results in a decrease in employee performance.

\section{Kaynakça / References}

Altunışık, R., Coşkun, R., Bayraktaroğlu, S., ve Yıldırım, E. (2012). Sosyal bilimlerde araştırma problemleri SPSS uygulamal (7. Baskı). Sakarya: Sakarya Kitabevi

Benligiray, S. (1999). İnsan kaynakları açısından otellerde performans yönetimi. Eskişehir: Anadolu Üniversitesi Yayınları.

Britton, D. M. (2000). The epistemology of the gendered organization. Gender and Society, 14(3), 418-434.

Brodsky, C.M. (1976), The harassed worker. Toronto-Lexington: Lexington Books

Çakıcı, A. (2010). Örgütlerde İşgören sessizliği: neden sessiz kalmayı tercih ediyoruz? Ankara: Detay Yayınclık.

Çalış Duman, M. ve Akdemir, B. (2016). Mobbing ve çalışan performansı arasındaki ilişkiyi belirlemeye yönelik bir araştırma. Akademik Yaklaşımlar Dergisi, 7(2), 29-52.

Çevik, H. H., Göksu, T., Bilgiç, V. K., Karakaya, M. S. Seyhan, K. ve Gül, S. K. (2008). Kamu kurumlarmnda performans yönetimi. Ankara: Seçkin Yayıncılık. 
Çınar, O. ve Akpunar, E. N. (2017). Mobbing ve ış performansına 1lişkin öğretmen algılarının çeşitli değişkenler açısından değerlendirilmesi. Mustafa Kemal Üniversitesi Sosyal Bilimler Enstitüsü Dergisi, 14(37), 41-58.

Çiçek Sağlam, A., ve Yüksel, A. (2015). Liselerde görev yapan öğretmen ve yöneticilerin örgütsel sessizliğe llişkin görüssleri. Turkish Studies, 10(7). 316-332.

Divincová, A., ve Sıváková, B. (2014). Mobbing at workplace and its impact on employee performance. Human Resources Management \& Ergonomics, 2, 20- 34.

Donaghey, J., Cullinane, N., Dundon, T. ve Wilkinson, A. (2011). Reconceptualising employee silence: Problems and prognosis. Work, Employment And Society, 25(1), 51-67.

Davenport, N., Schwartz, R., ve Elliott, G. (2003), Mobbing işyerinde duygusal taciz (Çev: O.Önertoy), İstanbul:SistemYayıncllk,.

Dyne, L. V., Ang, S. ve Botero, I. C. (2003). Conceptualizing employee silence and employee voice as multidimensional constructs. Journal of Management Studies, 40(6), 1359-1392.

Fırat İ., Ceyhan S., Çiçek, İ. ve Şanlı M. E (2019) Üniversite personelinin mobbinge yönelik algılarını bazı demografik değişkenler açısından değerlendirilmesi, Researcher: Social Science Studies, 6(4), 153-167.

Gardezi, F., Lingard, L., Espin, S., Whyte, S., Orser, B., ve Baker, G. R. (2009). Silence, power and communication in the operating room. Journal of Advanced Nursing. 65(7), 1390-1399

Gürer, A. ve Deniz, N. (2018). Çalışan sessizliğinin demografik özellikler açısından incelenmesi. Üçüncü Sektör Sosyal Ekonomi, 53(1), 91-110.

Hirschman, A. O. (1970). Exit, voice and loyalty. Cambridge, MA: Harvard University Press.

Hoel, H., Cooper, C.L., Faragher, B. (2001), The experience of bullying in great britain: The impact of organizational status. European Journal of Work and Organizational Psychology. 10, 443-465.

Korkmaz, M., Kılıç, B., Yücel, A. S., Gümüşdağ, H., ve Aksoy, M. (2014). Negative effects of mobbing on work performance and efficiency of personnel working in public and private medical institutions:An applied Turkey example. Advances in Environmental Biology, 8 (5), 1183-1195.

Kutanis, R Ö., Çetinel, E. (2014). Kadınların sessizliği: Devlet okullarındaki kadın öğretmenler üzerine bir araştırma. Amme İdaresi Dergisi, 47(1), 153-173.

Laleoğlu, A. ve Özmete, E. (2013), Mobbing ölçeği: Geçerlik ve güvenirlik Çalışması, Sosyal Politika Çalışmaları Dergisi, 31, 9-31. 
Leymann, H. (1990,) Important note in preface to heinz leymann, mobbing and psychological terror at workplaces, Violence and Victims, .5, 119-126.

Morrison, E. W. ve Milliken, F. J. (2000). Organizational silence: A barrier to change and development in a pluralistic world. Academy of Management Review. 706- 725.

Milliken, F. J., Morrison, E. W. ve Hewlin, P. F. (2003). An exploratory study of employee silence: Issues that employees don't communicate upward and why, Journal of Management Studies. 40(6), 1453-1476.

Pinder, C. C. ve Harlos, K. P. (2001). Employee silence: Quiescence and acquiescence as responses to perceived injustice. In Research In Personnel And Human Resources Management. 331-369.

Premeaux, S. F. ve Bedeian, A. G. (2003). Breaking the silence: The moderating effects of self-monitoring in predicting speaking up in the workplace, Journal of Management Studies. 40(6), 1537-1562.

Salin, D. (2003), Workplace bullying among business professionals-prevalance, organisational antecedents and gender differences, Unpublished Report, Swedish School of Economics and Business Administration, Helsingfors.

Şekerli, H. (2013). Öğretmenlerde çalışan sessizliği, ış doyumu ve denetim odağı. Yayımlanmamış Yüksek Lisans Tezi, Ankara Üniversitesi, Ankara.

Tayfun A., Çatır, O. (2013) Örgütsel sessizlik ve çalışanların performansları arasındaki ilişki üzerine bir araştırma. İşletme Araştırmaları Dergisi, 5(3) 114-134.

Thylfors, I. (1987), Scapegoats: On exclusions and bullying in work life, Stockholm, Sweden: Natur och Kultur.

TCK [Türk Ceza Kanunu] (t.y)., 18.10.2017 tarihinde http://www.cezabb.adalet.gov.tr/mevzuat/5237.htm adresinden erişilmiştir.

TDK [Türk Dil Kurumu] sözlük 18.10.2017 tarihinde https://sozluk.gov.tr/ adresinden erişilmiştir.

Tunçer, P. (2013) Örgütlerde performans değerlendirme ve motivasyon. Sayıştay Dergisi, 88, 87-108.

Ünsal, Artun (1996), Genişletilmiş bir şiddet tipolojisi, Cogito, 6-7. 29-36.

Westhues, K. (2003), The Mobbings at Medaille College in 2002, University of Waterloo,Canada.

Yalçın, B. ve Baykal, Ü. (2012). Özel hastanelerde görevli hemşirelerin sessiz kaldığı konular ve sessiz kalma nedenleriyle ilişkili faktörler. Hemşirelikte Eğitim ve Araştırma Dergisi, 9(2), 42-50. 
Yanık, C. (2012). Örgütsel sessizlik ile güven arasındaki ilişki ve eğitim örgütlerinde bir araştırma. Yayımlanmamiş Yüksek Lisans Tezi. Yeditepe Üniversitesi, İstanbul

Yazıcıoğlu, İ. (2010). Örgütlerde iş tatmini ve işgören performansi ilişkisi: Türkiye ve Kazakistan karşılaştırması. Bilig Türk Dünyası Sosyal Bilimler Dergisi, 55, 243264.

Yıldırım, A., ve Çarıkçı, O. (2017). Mesleki ve teknik anadolu liselerinde görev yapan eğitim yöneticisi ve öğretmenlerin örgütsel sessizlik düzeylerinin incelenmesi. Vizyoner Dergisi, 8(19), 33-43.

Zapf, D. (1999), Organizational work group related and personal causes of mobbing /bullying at work, International Journal of Manpower, 20, 70-85.

Zapf, D. ve Einarsen, S. (2001). Bullying in the workplace: Recent trends in research and practice-an introduction. European Journal of Work and Organizational Psychology, 10(4), 369-373.

\section{Kaynakça Bilgisi / Citation Information}

Yücekaya, P. ve İmamoğlu, Ö. (2020). Mobbingin, örgütsel sessizlik ve iş performansına etkisi: Çanakkale ilinde bir araştırma. OPUSUluslararası Toplum Araştırmaları Dergisi, 16(27), 319-352. DOI: 10.26466/opus.635147 